\title{
INVESTMENT DIVERSIFICATION AS A STRATEGY FOR REDUCING INVESTMENT RISK
}

\author{
Miljan Lekovic* \\ Faculty of Hotel Management and Tourism in Vrnjacka Banja, \\ University of Kragujevac, The Republic of Serbia
}

Investment diversification is a widely accepted investment strategy, aimed at reducing investment uncertainty, while simultaneously keeping the expected return on investment unaltered. The development of investment diversification coincided with the development of portfolio theory. At the time when traditional portfolio theory was recognized as the leading portfolio management practice, the simple diversification of investments was the most commonly used strategy; however, due to its inability to recognize the importance of the correlation between returns on different investments, simple diversification was later rejected in modern portfolio theory and replaced with efficient diversification. The research study is aimed at conducting a comparative analysis between the simple and efficient diversifications of investments, together with the inevitable analysis of the optimal number of securities in a portfolio and the testing of the validity of the international diversification of investments. By applying a qualitative research methodology, it is concluded that the benefits of the international diversification of investments are still substantial, and as such outweigh specific limitations, and that the number of securities in a portfolio should be increased as long as its marginal benefits, in the form of reduced investment risk, exceed its marginal costs - in terms of increased portfolio management costs, which also represents the main result of the research.

Keywords: simple diversification, efficient diversification, national diversification, international diversification

\section{JEL Classification: G11}

\section{INTRODUCTION}

Economic reality undoubtedly confirms the existence of the interrelatedness of and correlation between

\footnotetext{
* Correspondence to: M. Lekovic, Faculty of Hotel Management and Tourism in Vrnjacka Banja, University of Kragujevac, Vojvođanska 5A, 36210 Vrnjacka Banja, The Republic of Serbia; e-mail: m.lekovic@kg.ac.rs
}

return and risk as the basic postulates of modern financial theory. Due to the fact that return and risk are interdependent, any rational investor, in addition to estimating a future, expected return, seeks to identify and assess the risk of certain investment alternatives. In this regard, achieving the expected return is the key driver of an investment activity, while its maximization at the given level of risk is the main goal pursued by any investor. 
An investor who knows future returns with certainty will invest in only one security, namely the one with the highest future return (Markowitz, 1999). However, being certain about what the future holds is quite an unrealistic assumption that ignores risk and oversimplifies the investment process. Modern investors do not concentrate their wealth in a single security or a single type of securities; they rather invest their assets in different types of securities, thus building a diversified portfolio.

In terms of finance, an investment portfolio is a collection of different types of investments, i.e. a mix of different financial instruments held by investors. Holding a securities portfolio is a part of the investment strategy called the diversification of investments, which is carried out in order to reduce the total variance of a portfolio without changing the expected return. A simpler way to reduce portfolio risk is to allocate a portion of assets to risk-free assets. However, this strategy of risk reduction, quite opposite to diversification, would result in lower expected portfolio returns.

With regard to the above-mentioned, this research focuses on the analysis of the development process of the diversification of investments as an established investment risk reduction strategy.

The aim of the research is to examine the positive and negative aspects of the simple and efficient diversifications of investments, including the everpresent issue related to the selection of the optimal portfolio size and the comparison of the potential benefits and limitations of the international diversification of investments.

In accordance with the subject matter of the research study and the defined research goal, the initial hypothesis set out in this paper reads as follows:

$\mathrm{H}$ : The international diversification of investments, compared to the national diversification, achieves the same or a higher level of the expected return, including a further investment risk reduction.
The qualitative research method, based on the analytical description, is used in this study. This methodological toolkit makes it possible for the author to produce relevant conclusions about the research topics, based on the study of the relevant and for the most part foreign literature.

Taking into account the defined subject, goal and hypothesis, after the introductory considerations and the review of the relevant literature, this paper presents the analysis of the differences between the simple and the efficient diversifications of investments, which is followed by the identification of the disadvantages and limitations of diversification as an investment strategy. The paper continues by presenting the potential benefits and limitations of the international diversification of investments. In the last, concluding section of the paper, the opinions about the confirmation of the initial hypothesis are presented and the implications for future research considered.

\section{LITERATURE REVIEW}

The common concept of portfolio theory is that by combining different assets one can achieve better results than by simply investing funds in a single asset. The often-cited recommendation in the financial literature on how to allocate one's funds was written down in the IV century and reads as follows: "put a third in land, a third in merchandise and a third in cash". Although this idea had been around for centuries, it is during the mid-XX century that it actually took shape. In fact, before the emergence of modern portfolio theory (MPT), investors had used to construct their portfolios without considering the degree of the correlation between returns on different investment assets. The main disadvantage of this type of diversification, known as simple (naive) diversification, is that efficiency decreases as the number of assets in a portfolio increases (Jakšić \& Leković, 2015, 32). Being based on the "law of large numbers" - i.e. on holding a large number of securities in a portfolio, simple diversification results in an excessive diversification, which in turn results 
in high portfolio management costs. According to J. C. Francis and D. Kim (2013), simple diversification can reduce portfolio risk, but cannot minimize it since it ignores the correlation between returns on different assets.

Simple diversification and the application of the law of large numbers were first rejected by H. M. Markowitz (1952). The author points out that a portfolio with 60 different securities from a single industry would not be as well diversified as a same-size portfolio with securities from different industries. According to $\mathrm{H}$. M. Markowitz (1952), if one wants to make the variance small, it is not enough to invest in many securities, but it is necessary to avoid investing in securities with high covariances among themselves instead. Accordingly, H. M. Markowitz $(1952,89)$ suggests that we should diversify across different industries since companies in different industries, especially the industries with different economic characteristics, have lower covariances than the companies within a single industry. Therefore, H. M. Markowitz (1952) identified the importance of the correlation between the returns of individual securities in a portfolio; in this respect, a lower value of the correlation coefficient implies greater benefits from diversification. The founder of the MPT favors efficient diversification instead of simple diversification, i.e. recommends investing in low-correlated securities.

Unsystematic risk can be eliminated by efficient diversification, while the total investment risk can be reduced to the level of systematic risk. In the case of efficient national diversification, the lower limit in terms of risk reduction is actually the level of national systematic risk. However, in addition to national diversification, investors can also opt for international diversification. H. G. Grubel (1968) first pointed to the importance of international diversification and the possibility of reducing portfolio risk below the level of systematic risk. His viewpoint was supported by B. H. Solnik (1974), H. Levy and Z. Lerman (1988), W. Bailey and R. M. Stulz (1990) and the many others who emphasized the advantages of constructing an internationally diversified portfolio, i.e. the benefits of investing money in foreign securities. Unfortunately, due to the growing international market integration, the benefits of international diversification are being reduced - however, they are still significant and evident. The substantial benefits of international diversification are also supported by the research carried out by K. Li, A. Sarkar and Z. Wang (2003), R. Gupta (2006), W. J. P. Chiou (2009), C. S. Asness, R. Israelov and J. M. Liew (2011), O. Bouslama and O. B. Ouda (2014), G. Mansourfar, H. Didar and S. Jodatnia (2017) and others. K. Li et al (2003), R. Gupta (2006) and O. Bouslama and O. B. Ouda (2014) point out the fact that although the growing integration of different capital markets reduces the benefits of investing in foreign markets (especially the emerging markets), this does not necessarily mean that it eliminates them. The authors agree that emerging markets still represent an important component of a welldiversified portfolio. P. Christoffersen, V. R. Errunza, K. Jacobs and H. Langlois (2012) came up with the evidence supporting the aforementioned statement. The authors used the weekly rates of return of a large number of countries for the period 1973-2009, and found an increasing correlation between developed markets, as well as between emerging markets; the important conclusion of their research is that investing in emerging markets still brings significant benefits to investors.

In addition to selecting an optimal method for diversification, economists have been trying to determine an optimal number of securities in a portfolio for decades. The first study which measured the effects of an increase in the portfolio size on risk reduction for the purpose of determining the optimal size of a portfolio was carried out by J. L. Evans and S. H. Archer (1968), who found that, eight to ten securities in a portfolio on average are sufficient to achieve the largest number of benefits from diversification. The authors argue that a portfolio consisting of 15 securities is fully diversified, for which reason any further increase in the number of the securities held in that portfolio does not affect risk reduction. M. Statman (1987) rejected the above conclusion based on his research, which showed that an optimally diversified portfolio must include 30 securities at least. J. Y. Campbell, M. Lettau, B. G. Malkiel and Y. Xu (2001) point out that the number of the securities required in order to achieve the 
optimal portfolio diversification increases with an increase in unsystematic risk. The authors divided the observed period from 1963 to 1997 into the three sub-periods: 1963-1973, 1974-1985 and 1986-1997. They concluded as follows: in terms of the first two subperiods, most of the benefits from diversification were achieved by investing in 20 securities, whereas the similar effects of the diversification in the third subperiod were achieved by investing in 50 securities. $\mathrm{H}$. Benjelloun (2010) came to a similar conclusion about the optimal size of a portfolio and an increase in the optimal number of the securities held in a portfolio. He pointed out that, in order to achieve a sufficient diversification of investments, a portfolio must include between 40 and 50 securities.

While examining the efficiency of simple diversification, G. Y. N. Tang (2004) came to a conclusion that a 20-stock portfolio was good enough in terms of eliminating $95 \%$ of unsystematic risk, whereas the additional 80 stocks (the 100-stock portfolio) were required for the elimination of the additional $4 \%$ of such unsystematic risk $(99 \%$ of unsystematic risk). M. Statman $(2002,2004)$ and D. L. Domian, D. A. Lawton and M. D. Racine (2007) argue that the optimal number of stocks in a portfolio has increased from 10 to 15 stocks at the beginning of the 1950s to a hundred and over a hundred shares at the beginning of the XXI century.

Based on the example of the capital markets of the USA, the UK, Japan, Canada and Australia, V. Alexeev and F. Tapon (2013a) proved that the optimal number of securities in a portfolio depended on market conditions, and that this number increased during the periods of the financial and economic crisis. In this regard, the different capital markets have established different optimal portfolio sizes. Based on the survey they had conducted in the capital markets of Australia, V. Alexeev and F. Tapon (2013b), concluded that 24 to 30 shares were sufficient to construct a welldiversified portfolio. In terms of the capital market of Canada, the same authors found that the optimal portfolio size was that exceeding 50 shares (Alexeev \& Tapon, 2014). The results of the research carried out by M. R. Sarker (2013) in the capital market of Bangladesh indicate that the optimal portfolio consists of 33 shares, whereas the optimal number of shares in a portfolio in the capital market in Kenya, ranges from 18 to 22 shares, according to a survey conducted by S. E. Kisaka, J. A. Mbithi and H. Kitur (2015).

It should be noted that the research findings referring to the optimal size of a portfolio in the bond market are highly correlated with the findings relating to the stock market. The results of the study carried out by W. R. McEnally and M. C. Boardman (1979) indicate that between eight and 16 securities should be included in a portfolio so as to significantly reduce volatility, whereas recent studies, such as those conducted by W. Dbouk and L. Kryzanowski (2009), suggest that an optimal portfolio should include a greater number of components, which is generally estimated to be between 25 to 40 securities.

\section{THE SIMPLE AND EFFICIENT DIVERSIFICATIONS OF INVESTMENTS}

The traditional approach to increasing the number of securities in a portfolio for the purpose of reducing the total risk is known as simple (naive) diversification. According to this approach, investing in 100 different securities is ten times less risky than investing in 10 securities. The simple diversification of investments, based on the law of large numbers, was supported by the proponents of traditional portfolio theory: J. R. Hicks (1935), J. B. Williams (1938), D. H. Leavens (1945) and others, who separately evaluated individual securities, i.e. they did not make investment decisions within the context of a particular portfolio. Furthermore, they were not interested in determining the correlation between returns on individual securities within a portfolio. Traditional portfolio theory and its proponents did not recognize the importance of correlation for a portfolio construction. Correlation is important because it is essential for us to think about and make decisions based on the entire portfolio, rather than on individual securities. According to traditional portfolio theory, if investors want to eliminate risk, they should invest in a large number of securities; therefore, during the period when traditional portfolio theory was considered to 
be the most influential concept, portfolio performance was evaluated solely based on the actual return.

In addition to completely ignoring correlation, another important disadvantage of simple diversification is, usually, reflected in an excessive number of securities held in a portfolio. An excessive number of components in an investment portfolio lead to the high transaction costs related to both portfolio construction and portfolio management. Therefore, it can be concluded that simple diversification represents a traditional approach to diversification; however, it is still applied in practice by those investors and portfolio managers who use heuristics (mental shortcuts), such as the application of the $1 / \mathrm{N}$ rule.

Unlike traditional portfolio theory and simple diversification as its main characteristic, the MPT has shifted the emphasis from the analysis of the characteristics of the individual securities held in a portfolio to the analysis of the characteristics of the entire portfolio, simultaneously underlining the importance of the correlation between returns on held securities. If investors seek to reduce portfolio risk, they should not invest in a large number of different securities; they should rather invest in low-correlated securities (Jaksic, 2012, 161). H. M. Markowitz (1952) provided the mathematical proof that a proper diversification can indeed minimize the variance of a portfolio for a given level of return. He was the first scientist and author to have formally quantified the return-risk trade-off. Understanding the nature of the correlation between returns on different assets enabled the construction of the sets of the efficient portfolios that minimize risk for a given level of return, i.e. they maximize return for a given level of risk.

According to H. M. Markowitz (1952), efficient diversification implies that investors should avoid securities with high covariances among themselves when constructing their investment portfolios. In an extreme case of perfectly positively correlated securities, diversification has no effect on risk. However, in all other cases, namely in every instance where the correlation between returns on the securities is less than perfectly positive, such a diversification will help reduce risk without sacrificing the expected return. The strongest positive effects of diversification can be achieved if all of the elements of a portfolio are perfectly negatively correlated. However, a perfect negative correlation, i.e. the complete canceling out of the variability of returns on securities against each other is not realistic; this is rather an idealized image of reality. It is difficult to find uncorrelated or negatively correlated securities on financial markets. The most common case is a moderate positive correlation, which moderately adds to reducing portfolio risk.

Figure 1 shows the effect of Markowitz's efficient diversification for a portfolio composed of two securities: Security B and Security A.

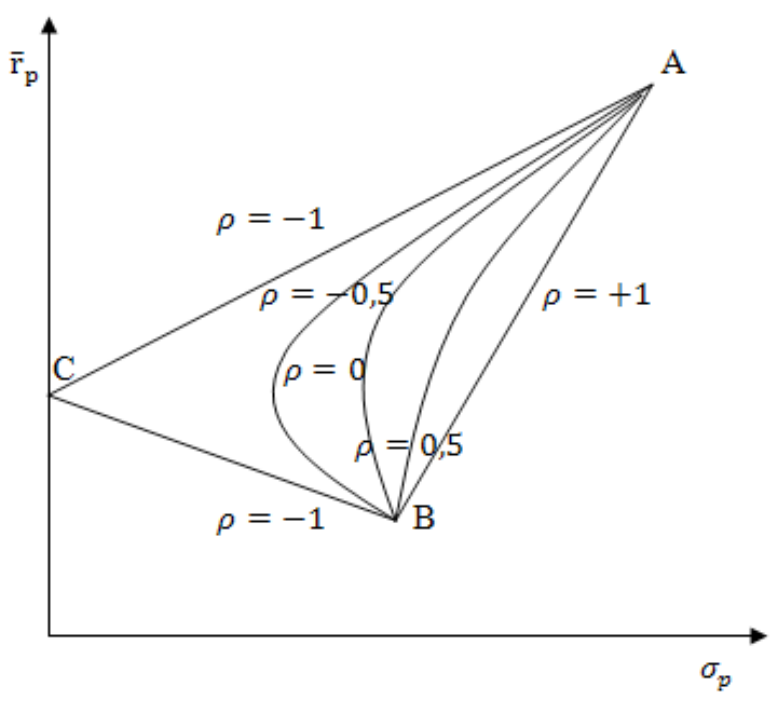

Figure 1 The effect of Markowitz's efficient diversification

Source: Author, based on: Francis \& Kim, 2013, 39

All the possible combinations of the positively correlated $(\rho=+1)$ B and A securities are represented by the straight line BA. Each point on this line marks the portfolio whose characteristics match the weighted characteristics of its components. This means that by combining the perfectly positively correlated A and B securities portfolio risk can be reduced; however, the expected return is also reduced in this manner. 
Starting from the point B and moving towards the point $A$, the expected return and portfolio risk grow due to the fact that the share of the riskier security that offers a higher return also increases. Starting from the opposite direction, i.e. from the point $\mathrm{A}$ and moving towards the point $B$, we see that both the expected return and portfolio risk become reduced. This supports the conclusion that diversification does not produce any benefits in the case of a perfect positive correlation among portfolio components.

On the other hand, all of the combinations of the negatively correlated $(\rho=-1)$ B and A securities are distributed along the two straight lines, the one of which (the line $\mathrm{BC}$ ) is negatively inclined, whereas the other (the line CA) is positively inclined. Moving from the point $B$ towards the point $C$ implies the inclusion of the riskier security $\mathrm{A}$ in the portfolio, which results in a decrease in the standard deviation of the portfolio and a concurrent increase in the expected return. If we were to assume an infinite divisibility of the observed securities, portfolio risk should be reduced to zero at the point $\mathrm{C}$. Therefore, portfolio diversification provides the complete stabilization of returns at the point $\mathrm{C}$. This is the ideal situation achieved due to a perfect negative correlation between the elements of a portfolio. By including the additional, riskier security A, portfolio returns continue to grow along the positive slope of the line CA; however, this is accompanied by a certain increase in portfolio risk (Figure 1).

Finally, by connecting the described straight line BA with the lines $\mathrm{BC}$ and $\mathrm{CA}$, we obtain a triangle $\mathrm{BCA}$, within which all the combinations of the imperfectly correlated $(-1<\rho<+1)$ B and A securities represented by the respective BA curves are contained. It is important to note that the curves BA initially have a negative slope due to the fact that the introduction of the riskier security A causes portfolio risk to briefly decrease because the correlation is less than perfectly positive. As the correlation coefficient decreases, the curves BA shift to the left, which actually illustrates an increase in benefits from diversification in terms of the stabilization of portfolio returns. Therefore, in the case of imperfectly correlated securities, portfolio risk is located between the zero value, attained due to the perfect negative correlation, and the maximum value, achieved as a result of an ideal positive correlation among the elements of a portfolio. The general conclusion is that an efficient diversification implies, as well as requires, a low coefficient of correlation (Figure 1).

According to M. Rubinstein (2002), H. M. Markowitz was hardly the first to recognize the desirability of diversification; however, he indeed was the first person to produce a mathematical formalization of the idea of the diversification of investments. H. M. Markowitz $(1952,77)$ rejects the rule that the investor should maximize discounted expected returns. This rule does not imply diversification, which is why it is rejected both as a hypothesis and as the maximum to guide investment behavior. According to $\mathrm{H}$. M. Markowitz (1999), the existence of uncertainty in terms of investment is the essential point in analyzing the behavior of a rational investor, whereas the diversification of investments is a reasonable and common practice, as it reduces the mentioned uncertainty.

The effect of the efficient diversification on reducing the mentioned uncertainty, i.e. investment risk, can be mathematically interpreted. The general formula used for the portfolio variance calculation is written as follows (Elton, Gruber, Brown \& Goetzmann, 2011, 58):

$$
\sigma_{p}^{2}=\sum_{i=1}^{n} w_{i}^{2} \sigma_{i}^{2}+\sum_{i=1}^{n} \sum_{\substack{j=1 \\ i \neq j}}^{n} w_{i} w_{j} \sigma_{i j},
$$

where:

$\sigma_{p}^{2}$ - the variance of the portfolio $p$,

$w_{i}$ - the share of the $i$-th security in the portfolio,

$w_{j}$ - the share of the $j$-th security in the portfolio,

$\sigma_{i j}$ - the covariance between returns on securities $i$ and $j$,

$n$ - the number of the securities held in the portfolio.

Assuming that all the elements of a portfolio are uncorrelated, i.e. that the covariance between their returns is equal to zero $\left(\sigma_{i j}=0\right)$, we rewrite the previous expression as: 


$$
\sigma_{p}^{2}=\sum_{i=1}^{n} w_{i}^{2} \sigma_{i}^{2}
$$

By introducing the additional assumption of the equal amount of the funds invested in each security $w_{i}=\frac{1}{n}$, Equation (2) is written as follows:

$$
\sigma_{p}^{2}=\sum_{i=1}^{n}\left(\frac{1}{n}\right)^{2} \sigma_{i}^{2}=\frac{1}{n} \sum_{i=1}^{n} \frac{\sigma_{i}^{2}}{n}=\frac{1}{n} \bar{\sigma}_{i}^{2} .
$$

The effect of efficient diversification on portfolio risk reduction, represented by the equation $\sigma_{p}^{2}=\frac{1}{n} \bar{\sigma}_{i}^{2}$, is evident. It is clear that the portfolio risk expressed by the variance $\left(\sigma_{p}^{2}\right)$ decreases as the number of the uncorrelated elements of the portfolio $(n)$ increases. For an extremely large number of uncorrelated elements in a portfolio, the portfolio variance approximates to zero.

However, in a real market environment, it is impossible to construct a portfolio which only includes uncorrelated securities; therefore, the effects of the diversification of investments are significantly weaker. Uncertainty cannot be completely eliminated solely by diversification. The idea is to eliminate unsystematic risk, thus leaving only systematic risk, which is defined by the beta (Vincent, 2011). If an investor implements effective diversification, his/her portfolio will not contain unsystematic risk (the risk inherent in the issuer's company, such as insolvency risk, failed promotional activities, labor strikes, etc.), but only systematic risk (the risk inherent in the entire market, such as the interest-rate risk, foreignexchange risk, inflation risks, etc.). Systematic risk is the risk compensated for by the market itself, whereas unsystematic risk is the risk which cannot be compensated for. Therefore, in terms of appropriately constructed portfolios, systematic risk - the risk that cannot be eliminated by implementing diversification - is the only type of risk considered as relevant.

Some authors, including I. Omisore, M. Yusuf and N. Christopher (2012), have quite interestingly put forward the idea that unsystematic risk can be eliminated by diversification; however, this is followed by an increase in systematic risk. Diversification compels portfolio managers to invest in different types of assets, thereby artificially increasing demand for such assets. In this way, this artificially increased demand drives up the asset prices, which if analyzed individually have a small real value. Therefore, the entire portfolio becomes more expensive, which in turn results in a lower probability of achieving the expected positive return, i.e. leads to an increase in portfolio risk.

Bearing this in mind, it can be concluded that effective diversification is desirable; however, it is not a perfect investment strategy. The benefits of diversification in terms of maintaining the same level of a portfolio's expected return (while reducing portfolio risk at the same time) achieved by combining assets with low or even negative correlation are evident. However, the problem here is to find negatively correlated assets since the most common type of correlation present in modern financial markets is a positive one. Also, in the conditions of a financial and economic crisis, correlation coefficients are close to 1, thereby reducing or completely eliminating the benefits of diversification. This is the major disadvantage of such an investment strategy because, if diversification does not produce the expected results in a situation when investors need to be protected from risk, the general usefulness of diversification must be considered. A financial and economic crisis and attempts to lower correlation coefficients are the factors that drive investors to invest their available funds not only in securities (primarily stocks and bonds), but also in new assets, such as precious metals, oil, real estate, works of art, and so on, and to include such assets in their portfolios. It should be noted that during financial and economic crises, the optimal number of securities held in a portfolio increases, which imposes higher costs in terms of portfolio management.

Certain empirical studies suggest that in the absence of constraints a simple diversification of investments is a more successful investment strategy in terms of reducing investment risk compared to efficient diversification. Based on the conducted comparative 
analysis, V. DeMiguel, L. Garlappi and R. Uppal (2009) determined that 14 optimal portfolio strategies showed inferior performance in comparison to the naive $1 / \mathrm{N}$ strategy. The authors specify the length of the time period analyzed and the number of assets, i.e. the elements of a portfolio, as the main criteria that determine the level of the success of the optimal portfolio strategies (optimal diversification) and the $1 / \mathrm{N}$ strategy (simple diversification), respectively. It is to be expected that optimal portfolio strategies will deliver better results than the $1 / \mathrm{N}$ strategy in the case where assessment refers to a long estimation window, and where the number of assets in a portfolio is small. Vice versa, it is expected that simple diversification will exceed optimal diversification if the number of assets in a portfolio is large and if the estimation of the expected return refers to a short estimation window. The key question that should be addressed in this matter is the critical length of the estimation window that would support specific models of the optimal allocation of assets in their achieving better results than the $1 / \mathrm{N}$ strategy. The aforementioned research, conducted on the US capital market, found that the critical length of the estimation window was 3000 months for the portfolio consisting of 25 assets, i.e. over 6000 months for the portfolio containing 50 assets. Bearing in mind the fact that the price estimates were generally done on the basis of the short-term sample of 60 to 120 months, the rationale supporting the determined superiority of the $1 / \mathrm{N}$ strategy is clear.

M. Kritzman, S. Page and D. Turkington (2010) argue that the application of the $1 / \mathrm{N}$ rule is not a viable alternative to the careful optimization of the portfolio, and consider the argumentation on the superiority of the $1 / \mathrm{N}$ strategy to be a misconception. The conclusion of their study is that the alleged superiority of the $1 / \mathrm{N}$ approach does not rest on the limitations of optimization, but rather on the forecasting based on the short estimation window. The results of the research conducted, based on the long-term estimation window, show that the performance of the optimized portfolios significantly exceeds the performance of the equally weighted $1 / \mathrm{N}$ portfolios, meaning that simple diversification thus loses its significance.

\section{POSSIBLE BENEFITS AND LIMITATIONS OF THE INTERNATIONAL DIVERSIFICATION OF INVESTMENTS}

By combining different types of securities traded on the financial market of a country, which are not perfectly positively correlated, the total variance, i.e. the total risk of a portfolio, is reduced. The lower limit of reducing the overall portfolio risk, achieved thanks to the national diversification of investments, actually represents national systematic risk. By reducing unsystematic risk, national diversification levels the total portfolio risk with national systematic risk (Figure 2).

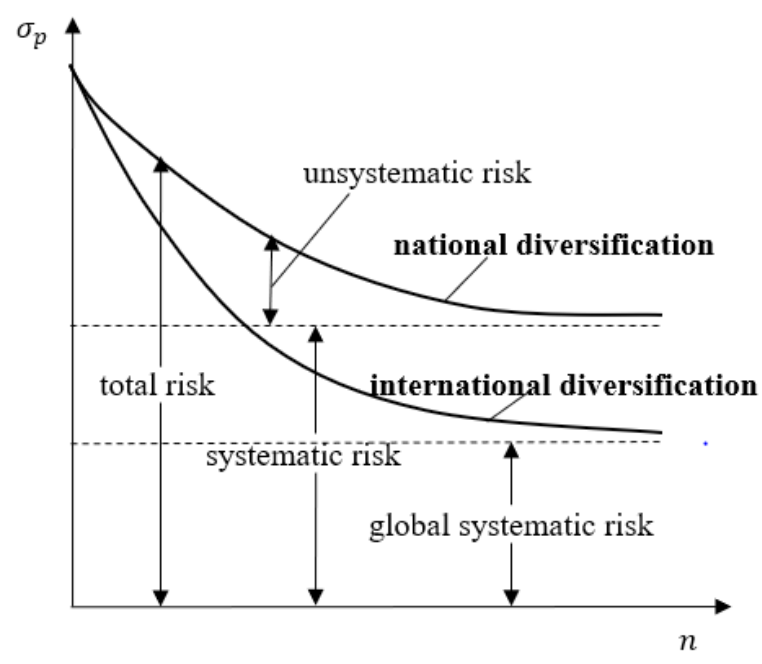

Figure 2 The effects of national and international diversifications

Source: Author

Lowering portfolio risk below the level of national systematic risk is made possible thanks to the international diversification of investments. By including foreign securities in a portfolio, one portion of the risk characterized as systematic risk in terms of the national market is transformed into unsystematic risk. The risk that remains after an effectively implemented international diversification is global systematic (market) risk, which cannot be avoided due to the fact that global macroeconomic factors affect all countries of the world. Therefore, 
international diversification transforms a portion of national systematic risk into unsystematic risk, thus contributing to a further risk reduction and bringing it to the level of global systematic risk (Figure 2). The conclusion is that the investor can reduce the risk exposure of individual assets by holding a nationally diversified portfolio of assets and lower the exposure to national systematic risk by holding an internationally diversified portfolio as well.

The adequacy of the international diversification of investments predominantly depends on the correlation among the financial markets of different countries. E. J. Elton et al (2011) calculated the correlation coefficients of the 15 stock indices of different world countries for the period 1990-2007 by using monthly returns data. The correlation among the stock indices of those different countries was 0.48 on average, and was two times smaller than the correlation between various stock indices in terms of a particular country. This illustrates the potential benefits of international diversification because, as a rule, a lower correlation coefficient results in a lower portfolio risk. However, the fact that the correlation between the markets of different countries increases from one year to another is a worrying one. This is confirmed by the calculations performed by the same authors for the previous period 1980-1988, where the value of the average correlation coefficient relating to international stock indices amounted to 0.40 . The increase in the correlation in the following period was a result of an increased integration of the world economy and the establishment of the European Monetary Union (EMU), as well as the increased correlation among the markets of the EMU member countries. However, despite this increase, the correlation among the international markets remained lower than the correlation relating to the market of a particular country. Therefore, it is reasonable to expect that international diversification will continue to reduce the total portfolio risk in the future.

R. A. De Santis and L. Sarno (2008) come up with the evidence in favor of the application of the international diversification of investments. By using the monthly data for the period 1991-2007 relating to 18 countries and the USA, the authors identified which capital markets of the 18 mentioned countries highly correlated with the US market and vice versa, which capital markets showed a weak correlation with the US market. In this way, the authors provided recommendations for US investors concerning the specific markets in which they should invest free assets in order to achieve the desired benefits of international diversification. The general conclusion is that, by combining the assets of a selected group of countries (weakly correlated ones), better results, i.e. greater benefits, are achieved than when combining the assets of all the countries of the world (the global portfolio), or the assets of a single country (the domestic or national portfolio).

The results of the research study analyzing the case of 23 developed countries in the period 19802005, conducted by G. Bekaert, R. J. Hordick and X. Zhang (2009), confirm still significant benefits of international diversification. The authors did not find evidence in favor of the increased correlation of returns, except in the case of European capital markets. The study even points out the fact that, in terms of the financial literature, "there is no definitive evidence that cross-country correlations are significantly and permanently higher now than they were, say, 10 years ago." At the same time, the authors acknowledge that the effects of globalization are obvious and that investors from America and Europe can achieve greater benefits by investing in the Far East; they, however, argue that the globalization process has not led to major and permanent changes in the international correlation yet.

From the viewpoint of Chinese investors, the usefulness of the international diversification of investments was examined and confirmed by $\mathrm{C}$. Jiang, Y. Ma and Y. An (2013). The Chinese capital market has become more strongly integrated with the international capital market, following the implementation of the new foreign-currency exchange system in 2005, which has reduced, but not eliminated, the benefits of international diversification. However, the authors acknowledge that the study did not include transaction costs, which leaves the following question open: if transaction costs were included in the analysis of the benefits of 
international diversification, would these benefits still manage to outperform associated costs?

A number of studies (Ramchand \& Susmel, 1997; Kunovac, 2011) analyzing the correlation between the capital markets of different countries have concluded that the international correlation is significantly higher in turbulent periods in comparison with quiet market periods. A turbulent period implies a period of high market volatility (high absolute returns), whereas a quiet period implies a period of low market volatility (low absolute return). L. Ramchand and R. Susmel (1997) found that the correlation between the US and other world capital markets (Japan, the United Kingdom, Germany, Canada) was on average two or three-and-a-half times higher during the turbulent period compared to the quiet market period. Similarly, by analyzing monthly returns, D. Kunovac (2011) determined that the correlation between the Croatian and foreign capital markets was on average more than two times higher in the turbulent period. The mentioned studies confirmed the existence of the phenomenon of asymmetric correlation. In terms of international diversification, the results of these studies suggest that the benefits of international diversification in a turbulent market period are limited and significantly lower than in a quiet period. During a quiet market period, correlation is lower and the benefits of international diversification are greater, whereas turbulent periods are characterized by an increase in correlation and the consequent diminishing of the benefits of diversification.

The previously described statement that correlation increases with an increase in the volatility level, i.e. that it is higher in the case of large absolute returns, was examined by F. Longin and B. Solnik (2001), who concluded that the above-mentioned statement applied in terms of the bear market, but not in terms of the bull market. The results of their research based on using the monthly rates of return in the period 1958-1996 showed that the correlation of the US capital market with the capital markets of Great Britain, France, Germany and Japan was growing in the conditions of the bear market and large negative returns, but was decreasing in the conditions of the bear market and large positive returns. Therefore, the correlation of large negative returns indicates a trend of growth, whereas the correlation of large positive returns indicates a decreasing trend and converges to zero. The authors conclude that correlation does not depend on the level of market volatility, but rather on the market trend. Volatility on its own does not affect correlation. In the context of international diversification, the results of the aforementioned research suggest that the benefits of international diversification in the conditions of the bear market are limited and considerably smaller than in the conditions of the bull market. In the conditions of the bull market, correlation is lower and the benefits of international diversification are greater, whereas the bear market is characterized by an increase in correlation and a consequent reduction in benefits from diversification.

On the example of the US capital market, A. Ang and J. Chen (2002) proved that the phenomenon of correlation asymmetry was not only the characteristic of international capital markets, but also of the capital markets of individual countries. The authors also found that the correlation between individual shares and the overall capital market is significantly higher in the conditions of the bear market compared to the bull market. In their study, they developed a model for measuring the degree of asymmetry and concluded that asymmetry was greater in the following cases: the shares of small companies in comparison with the shares of large ones, the past loser portfolios compared to the past winner portfolios, shares with a lower beta coefficient compared to those with a higher beta coefficient; in addition, the authors determined that there was no relation between the leverage and correlation asymmetries.

As the starting point of scientific papers and empirical studies, the evidence in favor of the phenomenon of correlation asymmetry has been found by L. Yuo and R. T. Daigler (2010), J. Danielsson (2011) and others. The authors reject the constant and linear correlation between returns of financial instruments, noting that the findings on the benefits of the international diversification based on the constant correlation are often misleading and incorrect. Therefore, the adoption of the final position 
on the presence or absence of the superiority of the international diversification of investments over national diversification is a difficult task that requires caution. This is supported by the numerous other factors that reduce the usefulness of international investment and international diversification, such as: trade restrictions, political barriers, restrictions on currency exchange, and so on. According to W. F. Sharpe, G. Alexander and J. V. Bailey (1995), investing in a foreign security carries the risk associated with that particular security on its domestic market, plus an additional risk in the form of political and foreignexchange risks. Political risk refers to the uncertainty regarding the possibilities of investors to convert a foreign currency into the local currency because the government of some foreign country may restrict, tax or completely ban the conversion of one currency to another. On the other hand, foreign-currency risk relates to the uncertainty about the exchange rate at which some foreign currency will be converted to the investor's local currency in the future. In other words, currency risk is expressed as the variability of the portfolio returns caused by fluctuations in the exchange rate, i.e. change in the exchange rates in terms of the domestic and foreign currencies.

Good news is that changes in the currency exchange rates of different countries are not highly correlated, for the reason of which fact exchangerate risk represents a small part of the total risk of an internationally diversified portfolio. Some authors, such as J. C. Van Horne and J. M. Wachowicz (2007), even argue that currency risk contributes to the success of international diversification, i.e. boosts its effectiveness. In addition, foreign-exchange risk can be reduced or even completely eliminated by hedging it with forwards or futures. The full protection against foreign-exchange risk is possible in the case of risk-free fixed-income securities. On the other hand, it is not possible to completely eliminate the foreignexchange risk related to the risky investments whose returns vary. Futures contracts can cover the expected cash flow; however, if the actual cash flow is greater than the expected, then a portion of the foreigncurrency funds must be converted to local currency at the forward exchange rate. The proponents of hedging warn that the investors who do not implement foreign-exchange risk hedging miss the opportunity to reduce portfolio risk without diminishing portfolio return. They point out that a significant reduction in the variability of portfolio returns can be achieved through hedging. On the other hand, the opponents of hedging opine that the costs of hedging exceed its benefits related to risk reduction. Namely, the total annual hedging costs are estimated at between $0.25 \%$ and $0.50 \%$ of the value of the hedged assets - this fact is sufficient to persuade the opponents that the hedging of foreign-exchange risk is not profitable (Sharpe et al, 1995, 976). According to B. H. Solnik (1974), if an investor in foreign securities does not protect him-/herself against the exchange rate fluctuations, he/she is in fact intentionally speculating on currencies. Foreign-currency risk, as well as any other financial risks, carries a potential reward; therefore, such a speculation can be quite profitable. The conclusion is that, in addition to reducing the level of risk, international diversification often generates higher returns because it involves a larger choice of investments and provides opportunities to make a profit from exchange-rate fluctuations.

Taking into account the uncertainty regarding the future price movements of foreign securities, as well as the uncertainty about the future exchange rates at which capital gains and dividends will be converted from some foreign currency to the investor's local currency, international investments can be classified as:

- investment in foreign securities and

- investment in a foreign currency.

In this respect, the total return on an international investment includes:

- the returns earned from investing in foreign securities and

- the returns earned from investing in a foreign currency.

The previous statement can be mathematically proved to be true; we start with an algebraic expression for calculating the actual rate of return on shares (Francis \& Kim, 2013, 411): 


$$
r_{c, i t}=\frac{\left(p_{c, i t}-p_{c, i t-1}\right)+d_{c, i t}}{p_{c, i t-1}}
$$

where:

$r_{c, i t}$ - the actual rate of return on shares of the company $i$, located in the country $c$, at the time $t$,

$p_{c, i t}$ - the share price of the company $i$, located in the country $c$, at the time $t$,

$p_{c, i t-1}$ - the share price of this company at the time $t-1$,

$d_{c, i t}$ - the dividend per share of this company.

However, from the standpoint of, say, some US investor, the actual rate of return on shares of the mentioned company is calculated by applying the following formula:

$$
r_{U S, i t}=\frac{\left(p_{c, i t}+d_{c, i t}\right)\left(x_{c, t}\right)-\left(p_{c, i t-1}\right)\left(x_{c, t-1}\right)}{p_{c, i t-1}\left(x_{c, t-1}\right)},
$$

where:

$r_{U S, i t}$ - the total rate of the return earned on the stock $i$ by a US investor,

$x_{c, t}$ - the exchange rate of the currency of the country $c$ against the US dollar at the time $t$, expressed in US dollars as per foreign-currency unit,

$x_{c, t-1}$ - the exchange rate of the currency of the country $c$ against the US dollar at the time $t-1$.

By simplifying this expression, the following expression is obtained:

$$
\begin{aligned}
r_{U S, i t} & =\left[\left(1+r_{c, i t}\right)\left(1+r_{x, t}\right)\right]-1= \\
& =r_{c, i t}+r_{x, t}+r_{c, i t} r_{x, t}
\end{aligned}
$$

where:

$r_{c, i t}$ - the rate of the return that the investor would earn if, as a national of the country $c$, he/she bought a portion of the shares offered for sale by the company $i$ at the time $t-1$ and sold them at the time $t$, (the domestic return on assets, i.e. the return on assets earned on the domestic market),

$r_{x, t}=\frac{\left(x_{c, t}-x_{c, t-1}\right)}{x_{c, t-1}}-$ the rate of the return generated by the foreign-exchange rate fluctuations,

$r_{c, i t} r_{x, t}$ - the effect of the changes in exchange rates on a capital gain (loss) and dividends.

The final expression in the equation presented above $\left(r_{c, i t} r_{x, t}\right)$ can be omitted since its result is significantly smaller than the results of the first two expressions (it is actually equal to their product, and as a rule, these values are smaller than 1.0), following which the following equation is obtained (Elton et al, 2011, 211):

$$
r_{U S, i t}=r_{c, i t}+r_{x, t}
$$

In this manner, we have proved that return on an international investment consists of:

- return on investment in a foreign asset (return on asset on its domestic market, which it was issued in) and

- return on investing in a foreign currency.

Furthermore, it is concluded that, in terms of investors from different countries, return on the same international investment differs due to differences in exchange rates.

By applying the previous approximation, the expected return $\left(\bar{r}_{U S, i t}\right)$ and the standard deviation of return on foreign stock $\left(\sigma_{U S, i t}\right)$, the equation below reads as follows (Elton et al, 2011, 211):

$$
\bar{r}_{U S, i t}=\bar{r}_{c, i t}+\bar{r}_{x, t}
$$

$$
\sigma_{U S, i t}=\sqrt{\sigma_{c, i t}^{2}+\sigma_{x, t}^{2}+2 \sigma_{c, i t x, t}} .
$$

Since the individual risks associated with investing 
internationally are weakly correlated, the total risk which an investor investing in foreign securities is exposed to is smaller than the sum of domestic risk and exchange risk. In this particular example, the standard deviation of the return on foreign stock $\left(\sigma_{u s, i t}\right)$ is smaller than the sum of the standard deviation of the return on this stock in terms of the domestic market $\left(\sigma_{c, i t}\right)$ and the standard deviation of the return generated by exchange-rate fluctuations $\left(\sigma_{x, t}\right)$, i.e. $\sigma_{u s, i t}$ $<\sigma_{c, i t}+\sigma_{x, t}$. This relationship is a result of the effects of two factors:

- there is a very low correlation between return on stock in terms of the domestic market and the return generated by exchange-rate fluctuations, so the last expression $\sigma_{c, i t x, t}$ approximates to zero;

- the root sum square of standard deviations is smaller than their simple sum.

It should be noted that international diversification contributes to a further reduction in portfolio risk; however, its benefits are constantly diminished from one year to another as a result of the international market integration and consequently of the increased correlation between the markets of different countries. The studies based on the data from the 1960s and the 1970 s point to a reduction in the variability of returns, i.e. portfolio risk, by about $50 \%$, as a direct result of international diversification, whereas recent studies have shown that international diversification reduces the variability of returns by less than $1 \%$. For example, while analyzing the influence of the international diversification in the period 1990-2007, E. J. Elton et al (2011) found out that the total investment risk could be reduced by only $0.6 \%$ by applying the optimal US and global portfolio mix. In this particular case, the minimal risk is achieved by investing $68 \%$ of assets in the US portfolio and the remaining $32 \%$ of assets in the global portfolio. The discussion presented in this paper points to the conclusion that although the benefits of the international diversification of investments have been significantly reduced, they still exist.

\section{CONCLUSION}

At the time when traditional portfolio theory was a commonly accepted concept, the simple diversification of investments based on the law of large numbers, meaning namely that the correlation among the returns of the individual securities held in a portfolio was ignored, which often resulted in an excessive number of investment portfolio components, and thereby in an excessive cost of portfolio management. Efficient diversification is the new model of investment diversification proposed by the MPT. This type of investment diversification takes into consideration the degree of the correlation among returns on individual securities, thus minimizing investment risk and including an optimal number of securities in a portfolio and also maintaining the same level of the expected return.

The number of securities in a portfolio required in order to achieve the satisfactory effects of diversification depends on the correlation among returns on individual securities. A positive correlation implies a larger number of securities, whereas a negative correlation requires a smaller number of securities to be included in an efficiently diversified portfolio. If there are a very small number of securities in a portfolio, that results in a potentially high unsystematic risk, whereas a large number of securities incur high transaction costs both in terms of creating such a portfolio and in terms of the high costs of portfolio management. The general conclusion is that the number of the securities held in a portfolio should be increased as long as its marginal benefits in the form of reduced investment risk reach the level of its marginal costs in terms of increased portfolio management costs. The equality of the marginal cost and marginal benefits is a condition for maximizing diversification benefits.

Due to the fact that the correlation among the financial markets of different countries is lower than the correlation in terms of a particular country and its market, investors are advised to opt for international diversification as an optimal investment strategy. Indeed, the effect of international diversification on risk reduction is diminished 
due to globalization and an increasing economic integration of countries. However, any risk reduction is significant; furthermore, if we also include the possibility of earning higher returns, which may be achieved based on a wider investment horizon (especially by investing in emerging markets) and favorable exchange-rate fluctuations, the benefits of international diversification are real and more than evident. By converting one part of national systematic risk into unsystematic risk, the international diversification of investments reduces the level of investment risk from the level of national systematic risk to the level of global systemic risk, simultaneously maintaining or even increasing the expected return on investment. Therefore, compared to national diversification, international diversification provides a better portfolio performance, which confirms the validity of the hypothesis.

A large number of studies argue that the benefits of the international diversification of investments are still substantial; however, many authors warn that the only way to come to a valid conclusion is to include a realistic assumption of asymmetric correlations. In this regard, a conclusion has been drawn that the benefits of international diversification in a quiet market period are greater than those in the period of market turbulence. Furthermore, it is concluded that during a turbulent period it is important that a distinction between the sub-periods of the bear market and the sub-periods of the bull market should be made because, in terms of the bull market, the benefits of international diversification are significantly higher compared to those in the bear market conditions. In short, the benefits of the diversification of international investments are the smallest in the conditions of the bear market since the correlation of large negative returns indicates the tendency of growth.

The empirical analysis of the benefits of the simple, efficient, national and international diversifications of investments followed by a corresponding comparative analysis was not carried out in this study, nor was the empirical analysis of the optimal size of a portfolio in terms of the Serbian capital market conducted, either, which is the key limitation of this paper.
Simultaneously, however, it makes an interesting suggestion for future research.

The opinions presented in this paper are aimed at emphasizing the importance of diversification as an investment strategy, as well as the importance of its advantages, disadvantages and limitations. By identifying the shortcomings and limitations, their significance is diminished, whereas the importance of diversification as an investment practice is improved. A particularly interesting fact is that, in the contemporary world, the optimal number of portfolio components exceeds 100; some investors, however, still hold three to four securities in their investment portfolios. This suggests the direction of future research: to try to analyze this issue, which is referred to as the diversification puzzle in the financial literature, which should include the elements of behavioral portfolio theory.

\section{REFERENCES}

Alexeev, V., \& Tapon, F. (2014). How many stocks are enough for diversifying Canadian institutional portfolios? Discussion Paper Series N 2014-08, University of Tasmania.

Ang, A., \& Chen, J. (2002). Asymmetric correlations of equity portfolios. Journal of Financial Economics, 63(3), 443-494. doi:10.1016/S0304-405X(02)00068-5

Bekaert, G., Hordick, R. J., \& Zhang, X. (2009). International stock return comovements. The Journal of Finance, 64(6), 2591-2626. doi:10.1111/j.1540-6261.2009.01512.x

Benjelloun, H. (2010). Evans and archer - Forty years later. Investment Management and Financial Innovations, 7(1), 98-104.

Bouslama, O., \& Ouda, O. B. (2014). International portfolio diversification benefits: The relevance of emerging markets. International Journal of Economics and Finance, 6(3), 200-215. doi:10.5539/ijef.v6n3p200

Cambell, J. Y., Lettau, M., Malkiel, B. G., \& Xu, Y. (2001). Have individual stocks become more volatile? An empirical exploration of idiosyncratic risk. The Journal of Finance, 56(1), 1-43. doi:10.1111/0022-1082.00318 
Christoffersen, P., Errunza, V. R., Jacobs, K., \& Langlois, H. (2012). Is the potential for international diversification disappearing? A dynamic copula approach. Review of Financial Studies, 25(12), 3711-3751. doi:10.2139/ssrn.2066076

Danielsson, J. (2011). Financial Risk Forecasting. Chichester, UK: John Wiley \& Sons Ltd.

Dbouk, W., \& Kryzanowski, L. (2009). Diversification benefits for bond portfolios. The European Journal of Finance, 15(5-6), 533-553. doi:10.1080/13518470902890758

De Santis, R. A., \& Sarno, L. (2008). Assessing the benefits of international portfolio diversification in bonds and stocks. Working Paper Series No 883, European Central Bank.

De Miguel, V., Garlappi, L., \& Uppal, R. (2009). Optimal versus naive diversification: How inefficient is the $1 / \mathrm{N}$ portfolio strategy? The Review of Financial Studies, 22(5), 1915-1953. doi:10.1093/rfs/hhm075

Domian, D. L., Louton, D. A., \& Racine, M. D. (2007). Diversification in portfolios of individual stocks: 100 stocks are not enough. Financial Review, 42(4), 557-570. doi:10.1111/ j.1540-6288.2007.00183.x

Elton, E. J., Gruber, M. J., Brown, S. J., \& Goetzmann, W. N. (2011). Modern Portfolio Theory and Investment Analysis. Hoboken, New Jersey: John-Wiley \& Sons Inc.

Evans, J. L., \& Archer, S. H. (1968). Diversification and the reduction of dispersion: An empirical analysis. The Journal of Finance, 23(5), 761-767. doi:10.1111/j.1540-6261.1968. tb00315.x

Francis, J. C., \& Kim, D. (2013). Modern Portfolio Theory: Foundations, Analysis and New Developments. Hoboken, New Jersey: John Wiley \& Sons, Inc.

Grubel, H. G. (1968). Internationally diversified portfolios: Welfare gains and capital flows. The American Economic Review, 58(5), 1299-1314.

Jaksic, M. (2012). Risk management of portfolio securities. Economichorizons, 14(3), 155-168. doi:10.5937/ekonhor1203151J

Jakšić, M., \& Leković, M. (2015). Upravljanje investicionim rizikom primenom savremene portfolio teorije. Megatrend revija, 12(1), 31-46.

Jiang, C., Ma, Y., \& An, Y. (2013). International diversification benefits: An investigation from the perspective of Chinese investors. China Finance Review International, 3(3), 225-249. doi:10.1108/CFRI-06-2012-0071
Kritzman, M., Page, S., \& Turkington, D. (2010). In defense of optimization: The fallacy of 1/N. Financial Analysts Journal, 66(2), 31-39. doi:10.2469/faj.v66.n2.6

Kunovac, D. (2011). Asymmetric correlations on the Croatian equity market. Financial theory and practice, 35(1), 1-24.

Levy, H., \& Lerman, Z. (1988). The benefits of international diversification in bonds. Financial Analysts Journal, 44(5), 5664. doi:10.2469/faj.v44.n5.56

Li, K., Sarkar, A., \& Wang, Z. (2003). Diversification benefits of emerging markets subject to portfolio constraints. Journal of Empirical Finance, 10(1-2), 57-80. doi:10.1016/S09275398(02)00027-0

Longin, F., \& Solnik, B. (2001). Extreme correlation of international equity markets. The Journal of Finance, 56(2), 649-676. doi:10.1111/0022-1082.00340

Mansourfar, G., Didar, H., \& Jodatnia, S. (2017). International portfolio diversification at industry level within South-East Asian stock markets. Iranian Journal of Management Studies (IJMS), 10(1), 91-112. doi:10.22059/ijms.2017.137736.671892

Markowitz, H. M. (1952). Portfolio selection. The Journal of Finace, 7(1), 77-91. doi:10.1111/j.1540-6261.1952.tb01525.x

Markowitz, H. M. (1999). The early history of portfolio theory: 1600-1690. Financial Analysts Journal, 55(4), 5-16. doi:10.2469/ faj.v55.n4.2281

McEnally, W. R., \& Boardman, M. C. (1979). Aspects of corporate bond portfolio diversification. The Journal of Financial Research, 2(1), 27-36. doi:10.1111/j.1475-6803.1979. tb00014.x

Omisore, I., Yusuf, M., \& Christopher, N. (2012). The modern portfolio theory as an investment decision tool. Journal of Accounting and Taxation, 4(2), 19-28. doi:10.5897/JAT11.036

Ramchand, L., \& Susmel, R. (1997). Volatility and cross correlation across major stock markets. Journal of Empirical Finance, 5(4), 397-416. doi:10.1016/S0927-5398(98)00003-6

Rubinstein, M. (2002). Markowitz's portfolio selection: A fifty-year retrospective. Journal of Finance, 57(3), 1041-1045. doi:10.1111/1540-6261.00453

Sharpe, W. F., Alexander, G. J., \& Bailey, J. V. (1995). Investments. Englewood Cliffs, New Jersey: Prentice Hall Inc. 
Solnik, B. H. (1974). Why not diversify internationally rather than domestically? Financial Analysts Journal, 30(4), 48-54. doi:10.2469/faj.v51.n1.1864

Statman, M. (1987). How many stocks make a diversified portfolio? Journal of Financial and Quantitative Analysis, 22(3), 353-363. doi:10.2307/2330969

Statman, M. (2002). How much diversification is enough? Working paper, Santa Clara University. doi:10.2139/ ssrn.365241

Tang, G. Y. N. (2004). How efficient is naive portfolio diversification? An educational note. Omega, 32(2), 155-160. doi:10.1016/j.omega.2003.10.002 van Horne, J. C., \& Wachowicz, J. M. (2007). Osnovi finansijskog menadžmenta. Beograd, Republika Srbija: Data status.

Vincent, S. (2011). Is portfolio theory harming your portfolio? Journal of Applied Research in Accounting and Finance, 6(1), 2-13. doi.org/10.2139/ssrn.1840734

Williams, J. B. (1938). The Theory of Investment Value. Cambridge, USA: Harvard University Press.

You, L., \& Daigler, R. T. (2010). Is international diversification really beneficial? Journal of Banking \& Finance, 34(1), 163-173.

Received on $17^{\text {th }}$ April 2018, after revision, accepted for publication on $22^{\text {nd }}$ August 2018

Published online on $27^{\text {th }}$ August 2018

Miljan Lekovic is an Assistant Professor at the Faculty of Hotel Management and Tourism in Vrnjačka Banja, University of Kragujevac, where he teaches Principles of Economics and National Economy. He received his doctorate from the Faculty of Economics, University of Kragujevac. His research interest is focused on the financial economics. 


\title{
DIVERSIFIKACIJA KAO INVESTICIONA STRATEGIJA SMANJENJA RIZIKA ULAGANJA
}

\author{
Miljan Leković* \\ Fakultet za hotelijerstvo i turizam u Vrnjačkoj Banji Univerziteta u Kragujevcu
}

Diversifikacija je opšteprihvaćena investiciona strategija koja ima za cilj smanjenje neizvesnosti ulaganja uz zadržavanje nepromenjenog očekivanog prinosa ulaganja. Razvoj diversifikacije ulaganja odvijao se paralelno sa razvojem portfolio teorije. U vreme važenja tradicionalne portfolio teorije, primenjivana je prosta diversifikacija ulaganja koja je, usled zanemarivanja korelacije među prinosima različitih investicionih plasmana, sa pojavom savremene portfolio teorije odbačena i zamenjena efikasnom diversifikacijom. Svrha istraživanja je uporedna analiza proste i efikasne diversifikacije ulaganja, uz neizbežno analiziranje optimalnog broja hartija od vrednosti u sastavu portfolija i ispitivanje opravdanosti primene međunarodne diversifikacije ulaganja. Primenom kvalitativne metodologije istraživanja zaključeno je da su koristi od međunarodne diversifikacije ulaganja još uvek respektabilne i da nadmašuju prateća ograničenja, kao i da broj hartija od vrednosti u sastavu portfolija treba povećavati sve dok se marginalne koristi od diversifikacije, u vidu smanjenog rizika ulaganja, ne izjednače sa marginalnim troškovima, u smislu povećanih troškova upravljanja portfoliom, što predstavlja glavni rezultat istraživanja.

Ključne reči: prosta diversifikacija, efikasna diversifikacija, nacionalna diversifikacija, međunarodna diversifikacija

\section{JEL Classification: G11}

\section{UVOD}

Ekonomska stvarnost nedvosmisleno potvrđuje povezanost i međusobnu uslovljenost prinosa i rizika, kao osnovnih postulata na kojima počiva savremena finansijska teorija. Budući da su prinos i rizik

* Korespondencija: M. Leković, Fakultet za hotelijerstvo i turizam u Vrnjačkoj Banji, Univerzitet u Kragujevcu, Vojvođanska 5A, 36210 Vrnjačka Banja, Republika Srbija; e-mail: m.lekovic@kg.ac.rs međusobno uslovljeni, svaki racionalan investitor, pored sagledavanja budućeg očekivanog prinosa, nastoji da identifikuje i valorizuje rizik određene investicione alternative. S tim $\mathrm{u}$ vezi, ostvarivanje prinosa je osnovni pokretač investicione aktivnosti, a njegovo maksimiranje, pri datom nivou rizika, osnovni cilj svakog investitora.

Investitor koji sa sigurnošću poznaje buduće prinose investiraće samo $\mathrm{u}$ jednu hartiju od vrednosti - onu koja ima najveći budući prinos (Markowitz, 1999). 
Međutim, sigurna budućnost je nerealna pretpostavka koja zanemaruje rizik i suviše pojednostavljuje proces investiranja. Savremeni investitori ne koncentrišu svoje bogatstvo u jednu hartiju od vrednosti ili jednu vrstu hartija od vrednosti, već investiraju raspoloživa sredstva u različite vrste vrednosnih papira, kreirajući diversifikovani portfolio.

U finansijama, portfolio predstavlja skup investicija različitih vrsta i karakteristika, tj. kombinaciju različitih finansijskih instrumenata $u$ posedu investitora. Držanje portfolija hartija od vrednosti je deo investicione strategije koja se naziva diversifikacija ulaganja, a koja se sprovodi sa ciljem redukovanja ukupne varijanse portfolija, uz nepromenjeni očekivani prinos portfolija. Jednostavniji način za smanjenje rizika portfolija je preusmeravanje dela sredstava $u$ bezrizičnu aktivu. Međutim, takav način smanjenja rizika, za razliku od diversifikacije, rezultirao bi smanjenjem očekivanog prinosa portfolija.

Imajući u vidu napred navedeno, predmet istraživanja je analiza razvojnog procesa diversifikacije kao ustaljene investicione strategije smanjenja rizika ulaganja.

Cilj istraživanja je ispitivanje pozitivnih i negativnih aspekata proste i efikasne diversifikacije ulaganja, uz uvek aktuelni izbor optimalne veličine portfolija i upoređivanje potencijalnih koristi i ograničenja međunarodne diversifikacije ulaganja.

Shodno opredeljenom predmetu i postavljenom cilju istraživanja, osnovna hipoteza rada je:

$\mathrm{H}$ : Međunarodna diversifikacija ulaganja, u poređenju sa nacionalnom diversifikacijom, omogućava ostvarenje istog, ili višeg nivoa očekivanog prinosa, uz dodatno smanjeni rizik ulaganja.

$\mathrm{U}$ istraživanju će biti primenjen metod kvalitativne ekonomske analize, zasnovan na analitičkoj deskripciji. Ovaj metodološki instrumentarijum omogućava da se proučavanjem relevantne, dominantno inostrane literature formulišu validni zaključci o istraživanoj problematici.
Vodeći računa o opredeljenom predmetu, cilju i definisanoj hipotezi, u radu će nakon uvodnih razmatranja i pregleda relevantne literature biti analizirane razlike između proste i efikasne diversifikacije ulaganja, uz neizbežno navođenje nedostataka i problema sa kojima se suočava diversifikacija kao investiciona strategija. Potom će biti predstavljane potencijalne koristi i ograničenja međunarodne diversifikacije ulaganja. U poslednjem, zaključnom delu rada sumiraće se stavovi o ispunjenosti osnovne hipoteze i sagledaće se otvorena pitanja značajna za buduća istraživanja.

\section{PREGLED LITERATURE}

U portfolio teoriji je poznata ideja da sekombinovanjem različitih aktiva mogu postići bolji rezultati nego plasiranjem finansijskih sredstava samo $u$ jednu aktivu. Predlog alokacije finansijskih sredstava zapisan u IV-om veku i često navođen u finansijskoj literaturi glasi: „pojedinac treba trećinu sredstava da uloži u zemlju, trećinu u robu i trećinu da drži u gotovini“. Iako je ova ideja vekovima poznata, ona je tek polovinom prošlog veka uobličena. Naime, pre nastanka savremene portfolio teorije (Modern Portfolio Theory - MPT) investitori su konstruisali portfolio ne vodeći računa o stepenu korelacije među prinosima različitih investicionih plasmana. Osnovni nedostatak takvog načina diversifikacije, poznatog kao prosta (naivna) diversifikacija (naive diversification), jeste smanjivanje efikasnosti sa povećanjem broja hartija od vrednosti koje ulaze u portfolio (Jakšić \& Leković, 2015, 32). Prosta diversifikacija, zasnovana na zakonu velikih brojeva, tj. na posedovanju velikog broja hartija od vrednosti u sastavu portfolija, rezultira prekomernom diversifikacijom koja za posledicu ima i visoke troškove upravljanja portfoliom. Prema J. C. Francis-u i D. Kim-u (2013), prosta diversifikacija može smanjiti rizik portfolija, ali ne može minimizirati rizik, budući da ignoriše korelaciju između prinosa aktiva.

Prostu diversifikaciju i upotrebu zakona velikih brojeva prvi je odbacio H. M. Markowitz (1952). On ističe da portfolio sastavljen od šestdeset različitih 
hartija od vrednosti iste industrije nije podjednako dobro diversifikovan kao portfolio sastavljen od istog broja hartija od vrednosti različitih industrija. Prema H. M. Markowitz-u (1952, 89), da bi se smanjila varijansa portfolija nije dovoljno investirati u veliki broj hartija od vrednosti, već je neophodno izbeći investiranje $\mathrm{u}$ hartije od vrednosti sa međusobno visokom kovarijansom. Imajući u vidu navedeno, on predlaže diversifikaciju između različitih industrija, jer preduzeća iz različitih industrija, naročito industrija sa različitim ekonomskim karakteristikama, imaju manju kovarijansu nego preduzeća iz iste industrije. Dakle, H. M. Markowitz (1952) je uočio važnost korelacije među prinosima pojedinačnih hartija od vrednosti u sastavu portfolija, pri čemu niži koeficijent korelacije implicira veće koristi od diversifikacije. Utemeljivač MPT je, nasuprot prostoj diversifikaciji, zagovarao efikasnu diversifikaciju (efficient diversification), tj. ulaganje sredstava u nisko korelisane hartije od vrednosti.

Efikasnom diversifikacijom je moguće eliminisati nesistemski rizik (unsystematiclfirm-specific/uniquel diversifiable/idiosyncratic risk) i ukupan rizik ulaganja svesti na nivo sistemskog rizika (systematic/market/nondiversifiable risk). Ukoliko je reč o efikasnoj nacionalnoj diversifikaciji, donja granica smanjivanja rizika je nivo nacionalnog sistemskog rizika. Međutim, pored nacionalne diversifikacije, investitorima stoji na raspolaganju i međunarodna diversifikacija. $\mathrm{Na}$ značaj međunarodne diversifikacije i mogućnost smanjenja rizika ispod nivoa nacionalnog sistemskog rizika među prvima je ukazao H. G. Grubel (1968). Njegov stav podržali su B. H. Solnik (1974), H. Levy i Z. Lerman (1988) i mnogi drugi, ističući prednosti kreiranja međunarodno diversifikovanog portfolija, odnosno, prednosti ulaganja novca u inostrane hartije od vrednosti. Nažalost, usled sve veće međunarodne tržišne integracije, koristi od međunarodne diversifikacije su se vremenom smanjile, ali su još uvek značajne i očigledne. U prilog još uvek respektabilnim koristima međunarodne diversifikacije govore istraživanja koja su sproveli K. Li, A. Sarkar i Z. Wang (2003), O. Bouslama i O. B. Ouda (2014), G. Mansourfar, H. Didar i S. Jodatnia (2017) i drugi. K. Li i ostali (2003) i O. Bouslama i O. B. Ouda (2014) ističu da sve veća integracija različitih tržišta kapitala umanjuje, ali ne eliminiše koristi od ulaganja sredstava u inostrana tržišta, naročito tržišta kapitala zemalja u razvoju (emerging markets). Autori su saglasni da tržišta kapitala zemalja u razvoju nastavljaju da figuriraju kao važna komponenta dobro diversifikovanog portfolija. Dokaze u korist prethodne tvrdnje pronašli su i P. Christoffersen, V. R. Errunza, K. Jacobs i H. Langlois (2012). Autori su upotrebom nedeljnih stopa prinosa na primeru velikog broja zemalja, za period 1973-2009, utvrdili rastuću korelaciju kako među razvijenim tržištima, tako i među tržištima u nastajanju, uz zaključak da ulaganje sredstava u tržišta u nastajanju još uvek donosi značajne koristi investitorima.

Pored izbora optimalne metode diversifikacije, pažnju ekonomista decenijama zaokupljuje i pitanje optimalnog broja hartija od vrednosti u sastavu portfolija. Prvo istraživanje kojim su mereni efekti rasta veličine portfolija na smanjenje rizika, a u cilju određivanja optimalne veličine portfolija, izvršili su J. L. Evans i S. H. Archer (1968), sa zaključkom da je u proseku od osam do deset akcija u sastavu portfolija dovoljno za postizanje najvećeg dela koristi od diversifikacije. Autori tvrde da je portfolio kreiran od petnaest akcija potpuno diversifikovan, zbog čega dalje povećanje broja akcija u sastavu portfolija ne utiče na smanjenje rizika. Prethodnu tvrdnju odbacio je M. Statman (1987), koji je u svom istraživanju pokazao da je najmanje trideset akcija potrebno za kreiranje optimalno diversifikovanog portfolija. J. Y. Cambell, M. Lettau, B. G. Malkiel i Y. Xu (2001) ističu da je sa porastom nesistemskog rizika porastao i broj akcija potreban za postizanje optimalne portfolio diversifikacije. Autori su analizirani period, 19631997, podelili na tri subperioda: 1963-1973, 1974-1985. i 1986-1997, sa zaključkom da se u prva dva subperioda najveći deo koristi od diversifikacije postizao ulaganjem $u$ dvadeset akcija, dok su se približno isti efekti diversifikacije $u$ trećem subperiodu postizali ulaganjem u pedeset akcija. Do sličnog zaključka o optimalnoj veličini portfolija i porastu optimalnog broja akcija u sastavu portfolija došao je H. Benjelloun (2010), koji ističe da je od četrdeset do pedeset akcija potrebno za postizanje zadovoljavajuće diversifikacije ulaganja, dok V. Alexeev i F. Tapon (2014) predlažu kreiranje portfolija većeg od pedeset akcija. 
M. Statman (2002) i D. L. Domian, D. A. Louton i M. D. Racine (2007) tvrde da je optimalan broj akcija u sastavu portfolija porastao sa deset do petanest akcija sa početka pedesetih godina $X X$-og veka na sto i više akcija na početku XXI-og veka. G. Y. N. Tang (2004) je, ispitujući efikasnost proste diversifikacije, zaključio da je portfolio od dvadeset akcija dovoljan za eliminaciju 95\% nesistemskog rizika, dok je dodatnih osamdeset akcija (portfolio veličine sto akcija) potrebno za eliminaciju dodatnih 4\% nesistemskog rizika (99\% nesistemskog rizika).

Treba istaći i da su zaključci istraživanja optimalne veličine portfolija na tržištu obveznica u visokoj korelaciji sa zaključcima koji se odnose na tržište akcija. Rezultati studije koju su sproveli W. R. McEnally i M. C. Boardman (1979), ukazuju da je od osam do šesnaest obveznica u sastavu portfolija dovoljno za značajno smanjenje volatilnosti, dok istraživanja novijeg datuma, poput onog koje su izvršili W. Dbouk i L. Kryzanowski (2009), sugerišu da optimalni portfolio uključuje veći broj komponenata, obično od dvadesetpet do četrdeset obveznica.

\section{PROSTA I EFIKASNA DIVERSIFIKACIJA ULAGANJA}

Tradicionalni pristup povećavanja broja hartija od vrednosti u sastavu portfolija u funkciji smanjenja ukupnog rizika portfolija poznat je kao prosta (naivna) diversifikacija. Prema ovom pristupu investicija u sto različitih hartija od vrednosti nosi deset puta niži rizik od investicije u deset takvih hartija od vrednosti. Prostu diversifikaciju ulaganja, zasnovanu na zakonu velikih brojeva, zagovarali su predstavnici tradicionalne portfolio teorije: J. B. Williams, J. R. Hicks, D. H. Leavens i drugi. Oni su izolovano vrednovali pojedinačne hartije od vrednosti, odnosno, investicione odluke nisu donosili u kontekstu portfolija. Takođe, zanemarili su određivanje uzajamnog odnosa prinosa pojedinačnih hartija od vrednosti u sastavu portfolija. Tradicionalna portfolio teorija i njeni predstavnici nisu uočili važnost korelacije prilikom konstruisanja portfolija. Korelacija, je važna, jer je bitno razmišljati i odlučivati u kontekstu portfolija, a ne u kontekstu pojedinačnih hartija od vrednosti. Prema tradicionalnoj portfolio teoriji, ukoliko investitori žele da eliminišu rizik, dovoljno je da investiraju u veliki broj hartija od vrednosti zbog čega su se u vreme važenja ove teorije performanse portfolija ocenjivale isključivo na osnovu ostvarene stope prinosa.

Osim zanemarivanja korelacije, važan nedostatak proste diversifikacije se ogleda u neretko prekomernom broju hartija od vrednosti u sastavu portfolija. Prekomeran broj komponenti portfolija uzrokuje visoke transakcione troškove prilikom kreiranja takvog portfolija i visoke troškove upravljanja portfoliom. Može se zaključiti da prosta diversifikacija predstavlja tradicionalni pristup diversifikaciji, ali se još uvek pojavljuje u investicionoj praksi i primenjuje od strane onih investitora $i$ portfolio menadžera koji se služe heuristikama (mentalnim prečicama), poput primene pravila 1/N.

Nasuprot tradicionalnoj portfolio teoriji i prostoj diversifikaciji kao njenoj karakteristici, MPT je pomerila akcenat sa analize karakteristika pojedinačnih hartija od vrednosti na analizu karakteristika portfolija, ističući značaj korelacije među prinosima komponentnih hartija od vrednosti. Ukoliko investitori nastoje da smanje rizik portfolija, nije dovoljno da investiraju u veliki broj različitih hartija od vrednosti, već je potrebno da investiraju u hartije od vrednosti čiji prinosi imaju nisku korelaciju (Jakšić, 2012, 161). H. M. Markowitz (1952) je dao matematički dokaz da odgovarajuća diversifikacija može minimizirati varijansu portfolija za dati nivo prinosa. On je prvi formalno kvantifikovao supstituciju (trade off) između prinosa i rizika. Obraćanje pažnje na to kako su prinosi aktive korelisani sa ostalom aktivom, omogućilo je kreiranje seta efikasnih portfolija koji minimiziraju rizik za dati nivo prinosa, odnosno, maksimiraju prinos za dati nivo rizika.

Prema H. M. Markowitz-u (1952), efikasna diversifikacija zahteva od investitora da prilikom formiranja portfolija izbegava hartije od vrednosti sa visokom korelacijom. U ekstremnom slučaju savršeno pozitivno korelisanih hartija od vrednosti, efekti 
diversifikacije na rizik će izostati. U svim ostalim slučajevima - kada je korelacija među prinosima hartija od vrednosti manje nego savršeno pozitivna, diversifikacija će doprineti smanjenju rizika bez žrtvovanja očekivanog prinosa. Najjači pozitivni efekti diversifikacije se postižu ukoliko su svi elementi portfolija savršeno negativno korelisani. Međutim, savršeno negativna korelacija, tj. potpuno međusobno poništavanje varijabilnosti prinosa hartija od vrednosti nije realnost, već idealizovana slika stvarnosti. Na finansijskim tržištima je teško pronaći nekorelisane i negativno korelisane hartije od vrednosti. Najčešći slučaj je umereno pozitivna korelacija, koja umereno doprinosi smanjenju rizika portfolija.

Na Slici 1 prikazan je efekat Markowitz-eve efikasne diversifikacije, za slučaj portfolija sastavljenog od dve hartije od vrednosti B i A.

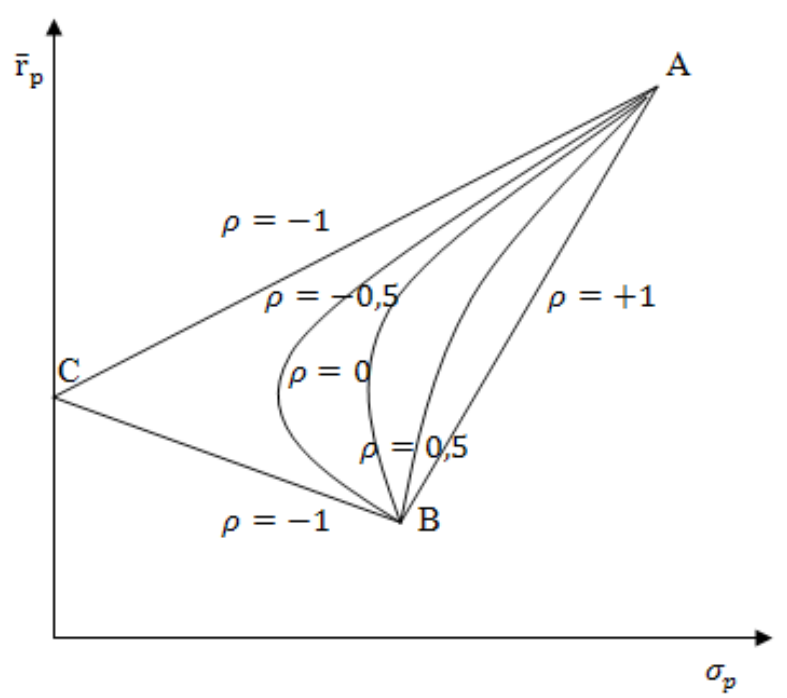

Slika 1 Efekat Markowitz-eve efikasne diversifikacije

Izvor: Autor, na osnovu: Francis \& Kim, 2013, 39

Sve moguće kombinacije savršeno pozitivno korelisanih $(\rho=+1)$ hartija od vrednosti B i A predstavljene su pravom linijom BA. Svaka tačka na ovoj pravoj označava portfolio čije se karakteristike podudaraju sa ponderisanim karakteristikama njegovih komponenata. To znači da se kombinovanjem savršeno pozitivno korelisanih hartija B i A ne može postići smanjenje rizika portfolija, koje nije praćeno istovremenim smanjenjem očekivanog prinosa. Krećući se od tačke B ka tački A očekivani prinos i rizik portfolija rastu, jer raste učešće rizičnije hartije od vrednosti koja nosi i veći prinos. U obrnutom slučaju, krećući se od tačke $\mathrm{A}$ ka tački B očekivani prinos i rizik portfolija se smanjuju. Navedeno potvrđuje izostanak koristi od diversifikacije u slučaju perfektne pozitivne korelacije između komponenti portfolija.

$S$ druge strane, sve kombinacije savršeno negativno korelisanih $(\rho=-1)$ hartija od vrednosti B i A raspoređuju se duž dve prave linije, od kojih je jedna linija negativnog nagiba (linija BC), a druga pozitivnog nagiba (linija CA). Kretanje od tačke B ka tački $C$ podrazumeva uključivanje rizičnije hartije od vrednosti A u portfolio, koje rezultira smanjivanjem standardne devijacije portfolija, uz istovremeni rast očekivanog prinosa. Ukoliko bi pretpostavili beskonačnu deljivost posmatranih hartija od vrednosti, rizik portfolija bi bilo moguće svesti na nulu u tački C. U tački C diversifikacija portfolija obezbeđuje potpunu stabilizaciju njegovog prinosa. U pitanju je optimalna situacija, postignuta zahvaljujući perfektnoj negativnoj korelaciji između elemenata portfolija. Dodatnim uključivanjem rizičnijeg vrednosnog papira A, duž linije pozitivnog nagiba CA, nastavlja se povećavanje očekivanog prinosa portfolija, ali po ceni rastućeg rizika (Slika 1).

Konačno, spajanjem opisane prave linije $\mathrm{BA}$ sa pravim linijama BC i CA, dobija se trougao BCA, $u$ čijem prostoru se nalaze sve kombinacije nesavršeno korelisanih $(-1<\rho<+1)$ hartija od vrednosti B i A, predstavljene krivim linijama BA. Važno je primetiti da su krive linije BA u početku negativnog nagiba, jer se uključivanjem rizičnije hartije od vrednosti A rizik portfolija nakratko smanjuje zahvaljujući činjenici da je korelacija manje nego savršeno pozitivna. Kako se koeficijent korelacije smanjuje, tako krive linije BA sve više tendiraju ulevo, što govori o povećavanju koristi od diversifikacije $\mathrm{u}$ smislu stabilizacije prinosa portfolija. Dakle, u slučaju nesavršeno korelisanih hartija od vrednosti, rizik portfolija se nalazi između nulte vrednosti postignute zahvaljujući savršeno negativnoj korelaciji i maksimalne vrednosti ostvarene kao posledica savršeno pozitivne korelacije 
između elemenata portfolija. Generalni zaključak je da efikasna diversifikacija podrazumeva i zahteva niske koeficijente korelacije (Slika 1).

Prema M. Rubinstein-u (2002), H. M. Markowitz nije bio prvi koji je shvatio poželjnost diversifikacije, ali je prvi dao matematičku formulaciju ideje o diversifikaciji investicija. Naime, H. M. Markowitz $(1952,77)$ je odbacio pravilo da investitor treba da maksimira diskontovanu vrednost budućih prinosa. Navedeno pravilo ne podrazumeva diversifikaciju i mora biti odbačeno i kao hipoteza i kao maksima. H. M. Markowitz (1999) smatra da je postojanje neizvesnosti ulaganja esencijalno $u$ analizi racionalnog investitorovog ponašanja, a diversifikacija ulaganja je uobičajena i razumna investiciona praksa, jer smanjuje ovu neizvesnost.

Uticaj efikasne diversifikacije na smanjenje pomenute neizvesnosti, tj. rizika ulaganja, može se matematički interpretirati. Opšta formula za varijansu portfolija glasi (Elton, Gruber, Brown \& Goetzmann, 2011, 58):

$$
\sigma_{p}^{2}=\sum_{i=1}^{n} w_{i}^{2} \sigma_{i}^{2}+\sum_{i=1}^{n} \sum_{\substack{j=1 \\ i \neq j}}^{n} w_{i} w_{j} \sigma_{i j}
$$

gde su:

$\sigma_{p}^{2}$ - varijansa portfolija $p$,

$w_{i}$ - udeo $i$-te hartije od vrednosti u portfoliju,

$w_{j}$ - udeo j-te hartije od vrednosti u portfoliju,

$\sigma_{i j}$ - kovarijansa prinosa hartija od vrednosti $i \mathrm{i} j$,

$n$ - broj hartija od vrednosti u portfoliju.

Pod pretpostavkom da su svi elementi portfolija međusobno nekorelisani, odnosno, da je kovarijansa između njihovih prinosa jednaka nuli $\left(\sigma_{i j}=0\right)$, prethodna jednačina se transformiše u sledeći izraz:

$$
\sigma_{p}^{2}=\sum_{i=1}^{n} w_{i}^{2} \sigma_{i}^{2}
$$

Uvođenjem dodatne pretpostavke o jednakom iznosu sredstava investiranom u svaku hartiju od vrednosti $w_{i}=\frac{1}{n}$, jednačina (2) dobija sledeći oblik:

$$
\sigma_{p}^{2}=\sum_{i=1}^{n}\left(\frac{1}{n}\right)^{2} \sigma_{i}^{2}=\frac{1}{n} \sum_{i=1}^{n} \frac{\sigma_{i}^{2}}{n}=\frac{1}{n} \bar{\sigma}_{i}^{2} .
$$

Uticaj efikasne diversifikacije na smanjenje rizika portfolija, predstavljen jednačinom $\sigma_{p}^{2}=\frac{1}{n} \bar{\sigma}_{i}^{2}$, je očigledan. Jasno je da se sa povećanjem broja nekorelisanih elemenata portfolija $(n)$, rizik portfolija iskazan varijansom $\left(\sigma_{p}^{2}\right)$ smanjuje. Za ekstremno veliki broj nekorelisanih elemenata portfolija, varijansa portfolija se približava nuli.

Međutim, u realnom tržišnom ambijentu je nemoguće kreirati portfolio sastavljen od nekorelisanih vrednosnih papira, pa su i efekti diversifikacije ulaganja znatno manji. Diversifikacijom se neizvesnost ulaganja ne može potpuno eliminisati. Namera je da se diversifikacijom eliminiše nesistemski rizik, ostavljajući samo sistemski rizik, definisan beta koeficijentom (Vincent, 2011). Ukoliko investitor sprovede efikasnu diversifikaciju, portfolio neće posedovati nesistemski rizik (rizik svojstven za kompaniju emitenta, poput rizika nelikvidnosti, neuspešne promotivne aktivnosti, štrajka radnika i sl.), već samo sistemski rizik (rizik svojstven za celokupno tržište, poput kamatnog, deviznog, inflacionog rizika i sl.). Sistemski rizik je rizik koji tržište kompenzuje, a nesistemski rizik je rizik za koji investitor ne dobija kompenzaciju. Prema tome, za pravilno kreirane portfolije jedini relevanti rizik je sistemski rizik - rizik koji se ne može otkloniti diversifikacijom.

Pojedini autori, poput I. Omisore-a, M. Yusuf-a i N. Christopher-a (2012), intrigantno tvrde da diversifikacija eliminiše nesistemski rizik, ali po cenu podizanja sistemskog rizika. Diversifikacija primorava portfolio menadžere da investiraju u različite vrste aktiva, čime se veštački povećava tražnja za njima. Ova veštački povećana tražnja uzrokuje rast cene aktive koja bi, analizirana individualno, imala malu osnovnu vrednost. Rezultat je da ukupan portfolio 
postaje skuplji, što za posledicu ima smanjenu verovatnoću ostvarenja očekivanog pozitivnog prinosa, odnosno, rast portfolio rizika.

Na osnovu navedenog, zaključuje se da je efikasna diversifikacija poželjna, ali ne i savršena investiciona strategija. Koristi od diversifikacije, u smislu zadržavanja očekivanog prinosa portfolija uz smanjeni rizik portfolija, postignute kombinovanjem aktive sa niskom ili još bolje negativnom korelacijom, su evidentne. Međutim, problem je pronalazak negativno korelisanih aktiva, budući da je pozitivna korelacija najčešći slučaj korelativne veze na savremenim finansijskim tržištima. Takođe, u uslovima finansijsko-ekonomskih kriza, koeficijenti korelacije teže jedinici, zbog čega se smanjuju ili potpuno nestaju prednosti diversifikacije. Ovo je ujedno i najveći nedostatak ove investicione strategije, jer ukoliko diversifikacija ne daje rezultate onda kada je investitorima najpotrebnija zaštita od rizika, postavlja se pitanje njene generalne upotrebljivosti. Upravo su finansijsko-ekonomske krize i namera da se smanje koeficijenti korelacije podstakli investitore da pored hartija od vrednosti (primarno akcija i obveznica) tragaju za novom aktivom, poput plemenitih metala, nafte, nekretnina, umetničkih dela i sl, i da je uključuju u portfolio. Treba istaći i da se $u$ vreme finansijsko-ekonomskih kriza povećava optimalan broj hartija od vrednosti u sastavu portfolija, što implicira i veće troškove upravljanja portfoliom.

Pojedina empirijska istraživanja sugerišu da je $u$ odsustvu ograničenja trgovanja prosta diversifikacija ulaganja uspešnija investiciona strategija smanjenja rizika ulaganja od efikasne diversifikacije. V. DeMiguel, L. Garlappi i R. Uppal (2009) su uporednom analizom utvrdili lošije performanse četrnaest optimalnih portfolio strategija u odnosu na naivnu $1 / \mathrm{N}$ strategiju. Kao osnovne kriterijume od kojih zavisi utvrđeni nivo uspešnosti optimalnih portfolio strategija (optimalne diversifikacije) i 1/N strategije (proste diversifikacije), autori navode dužinu analiziranog vremenskog perioda i broj aktiva, tj. elemenata portfolija. Za očekivati je da optimalne portfolio strategije donesu bolje rezultate od 1/N strategije, ukoliko je procenom obuhvaćen dug vremenski period (long estimation window) i ukoliko je broj aktiva u sastavu portfolija mali. I obrnuto, za očekivati je da prosta diversifikacija nadmaši optimalnu diversifikaciju ukoliko je broj aktiva u sastavu portfolija veliki i ukoliko se procena očekivanog prinosa odnosi na relativno kratak vremenski period. Ovde se, kao ključno, postavlja pitanje kritične dužine vremenskog perioda koji treba da bude obuhvaćen procenom (critical length of the estimation window), da bi modeli optimalne alokacije aktive doneli bolje rezultate od $1 / \mathrm{N}$ strategije. $\mathrm{U}$ opisanom istraživanju, sprovedenom na američkom tržištu kapitala, utvrđeno je da kritična dužina iznosi 3000 meseci za portfolio sastavljen od dvadesetpet aktiva, odnosno, više od 6000 meseci za portfolio koji sadrži pedeset aktiva. Imajući u vidu činjenicu da se procene u praksi obično vrše na osnovu kratkoročnog uzorka od šesdeset ili stodvadeset meseci, više nego jasan je razlog utvrđene superiornosti 1/N strategije.

Da primena $1 / \mathrm{N}$ pravila nije održiva alternativa pažljivoj optimizaciji portfolija tvrde M. Kritzman, S. Page i D. Turkington (2010), koji superiornost 1/N strategije nazivaju zabludom.

Zaključak njihove studije je da prividna superiornost 1/N pristupa ne proističe iz ograničenja optimizacije, već iz zasnovanosti procene očekivanih prinosa na kratkoročnom uzorku. Rezultati istraživanja sprovedenog na dugoročnim uzorcima pokazuju da performanse optimiziranih portfolija značajno nadmašuju performanse jednako ponderisanih 1/N portfolija, čime prosta diversifikacija gubi na značaju.

\section{POTENCIJALNE KORISTI I OGRANIČENJA MEĐUNARODNE DIVERSIFIKACIJE ULAGANJA}

Kombinovanjem različitih vrsta vrednosnih papira finansijskog tržišta jedne zemlje, koji nisu savršeno pozitivno korelisani, redukuje se ukupna varijansa, tj. ukupan rizik portfolija. Donja granica smanjenja ukupnog rizika portfolija, postignutog zahvaljujući nacionalnoj diversifikaciji ulaganja, jeste sistemski rizik nacionalnog tržišta. Nacionalna diversifikacija 
putem smanjivanja nesistemskog rizika, svodi ukupan rizik portfolija na nivo nacionalnog sistemskog rizika (Slika 2).

Dodatno smanjenje rizika portfolija ispod nivoa nacionalnog sistemskog rizika omogućava međunarodna diversifikacija ulaganja tako što, uključivanjem stranih hartija od vrednosti $u$ portfolio, jedan deo rizika koji je na nacionalnom tržištu okarakterisan kao sistemski transformiše u nesistemski. Rizik koji preostaje nakon efikasno sprovedene međunarodne diversifikacije ulaganja jeste globalni sistemski (tržišni) rizik, koji se ne može izbeći jer je posledica dejstva globalnih makroekonomskih faktora koji utiču na sve zemlje sveta. Dakle, međunarodna diversifikacija, transformacijom dela nacionalnog sistemskog $\mathrm{u}$ nesistemski rizik, doprinosi daljem smanjenju rizika portfolija na nivo globalnog sistemskog rizika (Slika 2). Zaključuje se da investitor može smanjiti izloženost riziku pojedinačne aktive držanjem nacionalno diversifikovanog portfolija aktive, ali i izloženost sistemskom riziku nacionalnog tržišta držanjem međunarodno diversifikovanog portfolija.

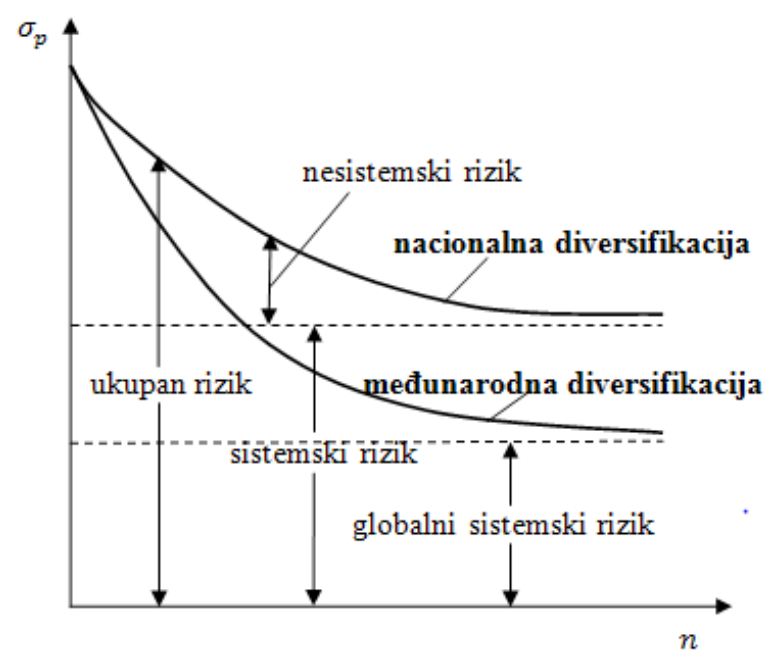

Slika 2 Efekat nacionalne i međunarodne diversifikacije

Izvor: Autor

Opravdanost međunarodne diversifikacije ulaganja dominantno zavisi od korelacije među finansijskim tržištima različitih zemalja. E. J. Elton i ostali (2011) su koristeći mesečne prinose, izračunali koeficijente korelacije između indeksa akcija petnaest zemalja sveta za period 1990-2007. Korelacija između indeksa akcija različitih zemalja je u proseku iznosila 0,48 i bila je duplo manja od korelacije između različitih indeksa akcija iste zemlje. Navedeno govori o potencijalnim koristima međunarodne diversifikacije, jer niži koeficijent korelacije, po pravilu, rezultira nižim rizikom portfolija. Međutim, ono što zabrinjava jeste činjenica da se korelacija između tržišta različitih zemalja iz godine u godinu povećava. To potvrđuje kalkulacija istih autora za raniji period, 1980-1988, kada je izračunat prosečan koeficijent korelacije između međunarodnih indeksa akcija $u$ iznosu od 0,40 . Rast korelacije u narednom periodu je usledio kao posledica pojačane integracije svetskih ekonomija i formiranja Evropske monetarne unije i povećane korelacije između tržišta njenih članica. Ipak, bez obzira na ovaj rast, korelacija između međunarodnih tržišta je ostala niža od korelacije unutar jedne zemlje i njenog tržišta. Stoga je za očekivati da međunarodna diversifikacija nastavi da vodi smanjivanju ukupnog rizika portfolija.

Dokaze $\mathrm{u}$ korist primene međunarodne diversifikacije ulaganja pronašli su i R. A. De Santis i L. Sarno (2008). Oni su, primenom mesečnih podataka za period 19912007. na primeru osamnaest zemalja i SAD, utvrdili sa kojim tržištima kapitala je američko tržište kapitala visoko, a sa kojima znatno niže korelisano. Na ovaj način, pružili su preporuke američkim investitorima po pitanju konkretnih tržišta u koja treba ulagati slobodna finansijska sredstva kako bi se ostvarile željene koristi od međunarodne diversifikacije. Generalni zaključak je da se kombinovanjem aktive odabrane (slabije korelisane) grupe zemalja postižu bolji rezultati, tj. veće koristi, nego kombinovanjem aktive svih zemalja sveta (globalni portfolio), ili pak kombinovanjem aktive jedne zemlje (domaći ili nacionalni portfolio).

Rezultati istraživanja koje su na primeru dvadesettri razvijene zemlje sveta, za period 1980-2005, sproveli G. Bekaert, R. J. Hordick i X Zhang (2009), potvrđuju još uvek značajne koristi od međunarodne diversifikacije. Oni nisu pronašli dokaze $\mathrm{u}$ korist trenda rasta 
korelacije prinosa, osim u slučaju evropskog tržišta kapitala. U studiji se čak ističe da u finansijskoj literaturi „ne postoje konačni dokazi da je korelacija među zemljama značajno i permanentno veća sada nego pre deset godina". Istovremeno, priznaju da su efekti globalizacije očigledni i da investitori iz Amerike i Evrope mogu ostvariti veće benefite ulaganjem sredstava u zemlje Dalekog istoka, ali tvrde da proces globalizacije još uvek nije doveo do velikih i trajnih promena u međunarodnoj korelaciji.

Korisnost međunarodne diversifikacije ulaganja iz ugla kineskih investitora, ispitivali su i potvrdili C. Jiang, Y. Ma i Y. An (2013). Kinesko tržište kapitala je postalo pojačano integrisano sa međunarodnim tržištem kapitala sa implementacijom novog deviznog sistema 2005, čime su se smanjile, ali ne i eliminisale koristi od međunarodne diversifikacije. Međutim, autori priznaju da istraživanjem nisu obuhvaćeni transakcioni troškovi, zbog čega je ostalo otvoreno pitanje da li i nakon uključivanja transakcionih troškova $\mathrm{u}$ analizu koristi od međunarodne diversifikacije uspevaju da nadmaše prateće troškove.

Brojne studije (Ramchand \& Susmel, 1997; Kunovac, 2011) su, istražujući korelaciju između tržišta kapitala, različitih zemalja zaključile da je međunarodna korelacija znatno veća $\mathrm{u}$ turbulentnim periodima $\mathrm{u}$ odnosu na mirna tržišna razdoblja. Pod turbulentnim periodom podrazumeva se period visoke tržišne volatilnosti (visokih apsolutnih prinosa), dok se pod mirnim periodom podrazumeva period niske tržišne volatilnosti (niskih apsolutnih prinosa). L. Ramchand i R. Susmel (1997) su utvrdili da je korelacija između američkog tržišta kapitala i drugih svetskih tržišta kapitala (Japana, Velike Britanije, Nemačke, Kanade), u proseku dva do tri i po puta veća u turbulentnom razdoblju u odnosu na mirno tržišno razdoblje. Slično, D. Kunovac (2011) je analizom mesečnih prinosa utvrdio da je korelacija hrvatskog sa stranim tržištima kapitala u proseku preko dva puta veća u turbulentnom razdoblju. Navedena istraživanja su potvrdila postojanje fenomena asimetričnih korelacija. U kontekstu međunarodne diversifikacije, rezultati ovih studija ukazuju da su koristi od međunarodne diversifikacije $u$ turbulentnom tržišnom razdoblju ograničene i znatno manje u odnosu na mirno tržišno razdoblje. U mirnom razdoblju korelacija je niža, a koristi od međunarodne diversifikacije veće, dok turbulentna razdoblja karakteriše porast korelacije i posledično umanjenje koristi od diversifikacije.

Prethodno opisanu tvrdnju da korelacija raste sa rastom nivoa volatilnosti prinosa, tj. da je veća $u$ slučaju velikih apsolutnih prinosa, ispitivali su F. Longin i B. Solnik (2001), sa zaključkom da navedeno važi u uslovima opadajućeg tržišta (bear market), ali ne i u uslovima rastućeg tržišta (bull market). Rezultati njihovog istraživanja, sprovedenog upotrebom mesečnih stopa prinosa, u periodu 1958-1996, pokazuju da korelacija američkog tržišta kapitala sa tržištima kapitala Velike Britanije, Francuske, Nemačke i Japana raste u uslovima opadajućeg tržišta i velikih negativnih prinosa, a smanjuje se $\mathrm{u}$ uslovima rastućeg tržišta i velikih pozitivnih prinosa. Dakle, korelacija velikih negativnih prinosa pokazuje tendenciju rasta, dok korelacija velikih pozitivnih prinosa pokazuje tendenciju pada i konvergira ka nuli. Autori zaključuju da korelacija ne zavisi od nivoa tržišne volatilnosti, već od tržišnog trenda. Volatilnost, sama po sebi, ne utiče na korelaciju. U kontekstu međunarodne diversifikacije, rezultati opisanog istraživanja ukazuju da su koristi od međunarodne diversifikacije $u$ uslovima opadajućeg tržišta ograničene i znatno manje $u$ odnosu na uslove rastućeg tržišta. U uslovima rastućeg tržišta korelacija je niža, a koristi od međunarodne diversifikacije veće, dok opadajuće tržište karakteriše porast korelacije i posledično umanjenje koristi od diversifikacije.

Da je fenomen asimetričnih korelacija odlika ne samo međunarodnog tržišta kapitala, već i tržišta kapitala pojedinačnih zemalja, na primeru američkog tržišta kapitala, dokazali su A. Ang i J. Chen (2002). Oni su utvrdili da je korelacija između pojedinačnih akcija i ukupnog tržišta kapitala znatno veća u uslovima opadajućeg tržišta u odnosu na uslove rastućeg tržišta. U studiji je razvijen model za merenje stepena asimetričnosti, sa zaključkom da je asimetričnost veća u slučaju: akcija malih preduzeća u odnosu na akcije velikih preduzeća, prošlih gubitničkih portfolija $u$ odnosu na prošle pobedničke portfolije, akcija sa nižim u odnosu na akcije sa višim beta koeficijentom, a utvrđeno je i odsustvo veze između leveridža i asimetrije. 
Dokaze u korist fenomena asimetričnih korelacija, kao polazne osnove naučnih radova i empirijskih istraživanja, pronašli su i L. Yuo i R. T. Daigler (2010), J. Danielsson (2011) i drugi. Autori odbacuju konstantnu i linearnu korelaciju među prinosima finansijskih instrumenata, ističući da su zaključci o koristima od međunarodne diversifikacije zasnovani na konstantnoj korelaciji neretko obmanjujući i pogrešni. Stoga je donošenje konačnog suda o prisustvu ili odsustvu superiornosti međunarodne diversifikacije ulaganja nad nacionalnom diversifikacijom težak zadatak koji zahteva opreznost. U prilog navedenom govore i brojni faktori koji umanjuju korisnost međunarodnog investiranja i međunarodne diversifikacije poput: trgovinskih restrikcija, političkih barijera, restrikcija u valutnoj razmeni i sl. Prema W. F. Sharpe, G. J. Alexander i J. V. Bailey (1995), investiranje u stranu hartiju od vrednosti uključuje ukupan rizik vezan za samu hartiju od vrednosti na njenom domaćem tržištu, plus dodatni rizik u vidu političkog i deviznog rizika. Politički rizik se odnosi na neizvesnost u vezi mogućnosti investitora da konvertuje stranu valutu u domaću, jer vlada strane zemlje može ograničiti, oporezovati ili potpuno zabraniti konverziju jedne valute u drugu. S druge strane, devizni rizik se odnosi na neizvesnost $\mathrm{u}$ pogledu kursa, po kome se strana valuta $\mathrm{u}$ budućnosti može zameniti za investitorovu domaću valutu. Drugim rečima, devizni rizik se izražava kao varijabilnost prinosa portfolija uzrokovana fluktuacijama deviznog kursa, tj. promenom razmenskog odnosa domaće i strane valute.

Dobra vest je da promene $\mathrm{u}$ razmenskim odnosima valuta različitih zemalja nisu u visokoj korelaciji, tako da rizik deviznog kursa predstavlja mali deo ukupnog rizika međunarodno diversifikovanog portfolija. Pojedini autori, poput J. C. van Horne-a i J. M. Wachowicz-a (2007), tvrde da devizni rizik doprinosi uspehu međunarodne diverifikacije, odnosno, povećava njen učinak. Takođe, devizni rizik se može smanjiti, pa čak i potpuno eliminisati, putem hedžinga forvardima ili fjučersima. Potpuna zaštita od deviznog rizika je moguća u slučaju bezrizičnih hartija od vrednosti sa fiksnim prinosom. S druge strane, nije moguće potpuno eliminisati devizni rizik vezan za rizične investicije čiji prinosi variraju. Terminski ugovori mogu pokriti očekivani novčani tok, ali ukoliko stvarni tok novca bude veći od očekivanog, tada jedan deo strane valute mora biti konvertovan u domaću valutu po važećem kursu u budućnosti. Zagovornici hedžinga upozoravaju da investitori koji ne sprovedu hedžing deviznog rizika, propuštaju priliku da smanje rizik portfolija bez umanjenja prinosa portfolija. Oni ističu da se putem hedžinga može postići značajno smanjenje varijabiliteta prinosa portfolija. Nasuprot zagovornicima, oponenti hedžinga smatraju da troškovi hedžinga premašuju njegove koristi u vidu smanjenja rizika. Naime, ukupni godišnji troškovi hedžinga se procenjuju između 0,25\% i 0,50\% vrednosti hedžovane aktive dovoljno da ubede oponente da je hedžing deviznog rizika neisplativ (Sharpe et al, 1995, 976). Prema B. H. Solnik-u (1974), ukoliko se investitor u strane hartije od vrednosti ne zaštiti od fluktuacija deviznog kursa, on praktično svesno vrši deviznu špekulaciju. Devizni rizik, kao i svaki drugi finansijski rizik, nosi potencijalnu nagradu, tako da špekulacije i te kako mogu biti profitabilne. Zaključak je da međunarodna diversifikacija, osim nižeg rizika, neretko donosi i potencijalno više prinose, jer podrazumeva, pre svega, veći izbor investicija, ali i mogućnost zarade po osnovu fluktuacija u deviznim kursevima.

Imajući u vidu neizvesnost budućih cena stranih vrednosnih papira, kao i neizvesnost budućeg deviznog kursa po kome će se kapitalni dobici i dividende konvertovati iz strane u domaću valutu investitora, međunarodna investicija se može podeliti na:

- investiciju u strane hartije od vrednosti, i

- investiciju u stranu valutu.

Saglasno navedenom, ukupan prinos od međunarodne investicije se sastoji od:

- prinosa koji donosi investiranje u strane hartije od vrednosti, $\mathrm{i}$

- prinosa koji donosi investiranje u stranu valutu.

Prethodna tvrdnja se može i matematički dokazati, a polazna tačka je algebarski izraz za stvarnu stopu prinosa na akcije (Francis \& Kim, 2013, 411): 


$$
r_{c, i t}=\frac{\left(p_{c, i t}-p_{c, i t-1}\right)+d_{c, i t}}{p_{c, i t-1}},
$$

gde su:

$r_{c, i t}$ - stvarna stopa prinosa na akcije preduzeća $i$ lociranog u zemlji c u vremenu $t$,

$p_{c, i t}$ - cena akcije preduzeća $i$ lociranog u zemlji $c \mathrm{u}$ vremenu $t$,

$p_{c, i t-1}$ - cena akcije ovog preduzeća u vremenu $t-1$,

$d_{c, i t}$ - dividenda po akciji ovog preduzeća.

Međutim, iz ugla američkog investitora, stvarna stopa prinosa na akcije pomenutog preduzeća se dobija primenom sledeće formule:

$$
r_{U S, i t}=\frac{\left(p_{c, i t}+d_{c, i t}\right)\left(x_{c, t}\right)-\left(p_{c, i t-1}\right)\left(x_{c, t-1}\right)}{p_{c, i t-1}\left(x_{c, t-1}\right)}
$$

gde su:

$r_{\text {us,it }}$ - ukupna stopa prinosa koju američkom investitoru donosi akcija $i$,

$x_{c, t}$ - devizni kurs između valute zemlje $c$ i američkog dolara $\mathrm{u}$ vremenu $t$, izražen $\mathrm{u}$ dolarima po jedinici strane valute,

$x_{c, t-1}$ - devizni kurs između valute zemlje $c$ i američkog dolara u vremenu $t-1$.

Simplifikovanjem dalje sledi:

$$
\begin{aligned}
r_{U S, i t} & =\left[\left(1+r_{c, i t}\right)\left(1+r_{x, t}\right)\right]-1= \\
& =r_{c, i t}+r_{x, t}+r_{c, i t} r_{x, t}
\end{aligned},
$$

gde su:

$r_{c, i t}$ - stopa prinosa koju bi investitor zaradio ako bi kao građanin zemlje $c$ kupio deo akcija preduzeća $i \mathrm{u}$ vremenu $t$ - 1 , i prodao ih u vremenu $t$, (domaći prinos aktive, tj. prinos aktive u okviru domaćeg tržišta), $r_{x, t}=\frac{\left(x_{c, t}-x_{c, t-1}\right)}{x_{c, t-1}}$ - stopa prinosa koju donose promene $\mathrm{u}$ deviznom kursu,

$r_{c, i t} r_{x, t}$ - efekat koji promena deviznog kursa ima na kapitalni dobitak (gubitak) i dividende.

Poslednji izraz u gornjoj jednačini $\left(r_{c, i t} r_{x, t}\right)$ može se izostaviti, pošto je znatno manji od prethodna dva (jednak je njihovom proizvodu, a oni su po pravilu manji od 1,0), tako da je približno (Elton et al, 2011, 211):

$$
r_{U S, i t}=r_{c, i t}+r_{x, t}
$$

Na ovaj način, dokazano je da se prinos od međunarodne investicije sastoji od:

- prinosa koji donosi investiranje u stranu aktivu (prinos aktive u okviru njenog domaćeg tržišta na kome je izdata), i

- prinosa koji donosi investiranje u stranu valutu.

Takođe, zaključuje se i da je prinos koji donosi ista međunarodna investicija različit za investitore različitih zemalja, zbog razlika u deviznim kursevima.

Koristeći prethodnu aproksimaciju, očekivani prinos $\left(\bar{r}_{U S, i t}\right)$ i standardna devijacija prinosa na stranu akciju $\left(\sigma_{U S, i t}\right)$ biće (Elton et al, 2011, 211):

$$
\bar{r}_{U S, i t}=\bar{r}_{c, i t}+\bar{r}_{x, t}
$$

$$
\sigma_{U S, i t}=\sqrt{\sigma_{c, i t}{ }^{2}+\sigma_{x, t}{ }^{2}+2 \sigma_{c, i t x, t}}
$$

Pošto su rizici koji prate međunarodno investiranje nisko korelisani, ukupan rizik investitora koji investira u strane hartije od vrednosti (total risk) je manji od zbira rizika promene cene na tržištu na kome je hartija emitovana (domestic risk) i deviznog rizika (exchange risk). U konkretnom primeru, standardna devijacija prinosa na stranu akciju $\left(\sigma_{\text {us,it }}\right)$ je manja od zbira standardne devijacije prinosa posmatrane akcije 
u okviru domaćeg tržišta $\left(\sigma_{c, i t}\right)$ i standardne devijacije prinosa ostvarenog po osnovu promena u deviznom kursu $\left(\sigma_{x, t}\right)$, odnosno, $\sigma_{\text {US,it }}<\sigma_{c, i t}+\sigma_{x, t}$. Ovaj odnos proizilazi kao posledica uticaja dva faktora:

- postoji veoma niska korelacija između prinosa akcije u okviru domaćeg tržišta i prinosa ostvarenog po osnovu promene $u$ deviznom kursu, zbog čega poslednji izraz $\sigma_{c, i t x, t}$ teži nuli, i

- kvadratni koren zbira kvadriranih standardnih devijacija je manji od njihovog prostog zbira.

Može se zaključiti da međunarodna diversifikacija doprinosi dodatnom smanjenju rizika portfolija, ali se koristi od međunarodne diversifikacije iz godine $u$ godinu smanjuju kao posledica međunarodne tržišne integracije, i posledično, povećane korelacije između tržišta različitih zemalja sveta. Istraživanja zasnovana na podacima iz 1960-tih i 1970-tih godina ukazuju na smanjenje promenljivosti prinosa, odnosno, rizika portfolija za oko 50\% kao direktan rezultat međunarodne diversifikacije, dok novija istraživanja svedoče o smanjenju promenljivosti prinosa za manje od 1\%. Primera radi, E. J. Elton i ostali (2011) $\mathrm{su}$, ispitujući uticaj međunarodne diversifikacije u periodu 1990-2007, ustanovili da se optimalnom kombinacijom američkog i svetskog portfolija ukupan rizik ulaganja može smanjiti za svega $0,6 \%$. U konkretnom slučaju, minimalni rizik je postignut investiranjem 68\% sredstava u američki portfolio, a preostalih $32 \%$ sredstava u svetski portfolio. Navedeno govori u prilog značajno smanjenih, ali još uvek prisutnih koristi od međunarodne diversifikacije ulaganja.

\section{ZAKLJUČAK}

Prosta diversifikacija ulaganja sprovođena $u$ vreme važenja tradicionalne portfolio teorije se zasnivala na zakonu velikih brojeva, tj. ignorisanju korelacije među prinosima pojedinačnih hartija od vrednosti u sastavu portfolija, rezultirajući neretko prekomernim brojem komponenti portfolija i prekomernim troškovima upravljanja portfoliom. Novi oblik diversifikacije ulaganja koji predlaže MPT je efikasna diversifikacija ulaganja, koja uzimanjem u obzir stepena povezanosti prinosa pojedinačnih hartija od vrednosti omogućava minimiziranje rizika ulaganja, uz optimalan broj hartija od vrednosti u sastavu portfolija i nepromenjen nivo očekivanog prinosa ulaganja.

Broj hartija od vrednosti u sastavu portfolija, potreban da bi se postigli zadovoljavajući efekti diversifikacije, zavisi od korelacije među prinosima hartija od vrednosti. Pozitivna korelacija implicira veći, a negativna korelacija manji zahtevani broj hartija od vrednosti u sastavu efikasno diversifikovanog portfolija. Suviše mali broj hartija od vrednosti u sastavu portfolija ima za posledicu potencijalno visok nesistemski rizik, dok preveliki broj hartija od vrednosti uzrokuje visoke transakcione troškove koji nastaju prilikom kreiranja takvog portfolija i visoke troškove upravljanja portfoliom. Zaključak je da broj hartija od vrednosti u sastavu portfolija treba povećavati sve dok se marginalne koristi od diversifikacije, u vidu smanjenog rizika ulaganja, ne izjednače sa marginalnim troškovima, u smislu povećanih troškova upravljanja portfoliom. Jednakost marginalnih troškova i marginalnih koristi je uslov maksimiranja korisnosti diversifikacije.

Budući da je korelacija među finansijskim tržištima različitih zemalja niža od korelacije unutar jedne zemlje i njenog tržišta, investitorima se predlaže primena međunarodne diversifikacije kao optimalne investicione strategije. Istini za volju, globalizacija i sve veća ekonomska integracija zemalja nesumnjivo smanjuju učinak međunarodne diversifikacije na polju redukcije rizika. Međutim, i najmanje smanjenje rizika je značajno, a ukoliko se navedenom dodaju i potencijalno viši prinosi, koji mogu biti ostvareni zahvaljujući širem investicionom horizontu (naročito ulaganjem sredstava $u$ tržišta kapitala zemalja $u$ razvoju) i zahvaljujući povoljnim fluktuacijama deviznog kursa, jasno je da su koristi od međunarodne diversifikacije još uvek realne i više nego očigledne. Međunarodna diversifikacija ulaganja, pretvaranjem dela nacionalnog sistemskog rizika u nesistemski, rezultira smanjenjem rizika ulaganja sa nivoa nacionalnog sistemskog na nivo globalnog sistemskog rizika, uz nepromenjen, ili viši očekivani prinos 
ulaganja. Samim tim, međunarodna diversifikacija, $\mathrm{u}$ poređenju sa nacionalnom diversifikacijom, obezbeđuje bolje performanse portfolija, čime je potvrđena hipoteza.

U prilog još uvek respektabilnim koristima međunarodne diversifikacije ulaganja govori većina istraživanja, ali mnogi autori upozoravaju da je jedino validno ono zaključivanje koje je zasnovano na realnoj pretpostavci asimetričnih korelacija. S tim u vezi, zaključeno je da su koristi od međunarodne diversifikacije $u$ mirnom tržišnom razdoblju veće $u$ odnosu na turbulentno tržišno razdoblje. Takođe, zaključeno je da je u okviru turbulentnog razdoblja važno izvršiti distinkciju između subperioda opadajućeg i subperioda rastućeg tržišta, jer su koristi od međunarodne diversifikacije u uslovima rastućeg tržišta znatno veće u poređenju sa uslovima opadajućeg tržišta. Ukratko, koristi od međunarodne diversifikacije ulaganja su najmanje $u$ uslovima opadajućeg tržišta, jer korelacija velikih negativnih prinosa pokazuje tendenciju rasta.

U sprovedenom istraživanju nije izvršena empirijska analiza korisnosti proste, efikasne, nacionalne i međunarodne diversifikacije ulaganja praćena odgovarajućom uporednom analizom, niti empirijska analiza optimalne veličine portfolija na tržištu kapitala Republike Srbije, što predstavlja ključno ograničenje rada, ali istovremeno i predlog za buduća istraživanja. Posebno intrigira činjenica da je u savremeno doba optimalan broj komponenata portfolija porastao na preko sto, a da pojedinačni investitori u svom portfoliju neretko drže svega tri do četiri hartije od vrednosti. Buduća istraživanja biće usmerena upravo na razmatranje ovog pitanja, poznatog u finansijskoj literaturi pod nazivom diversification puzzle, čemu će poslužiti elementi bihejvioralne portfolio teorije.

\section{REFERENCE}

Alexeev, V., \& Tapon, F. (2014). How many stocks are enough for diversifying Canadian institutional portfolios? Discussion Paper Series N 2014-08, University of Tasmania.
Ang, A., \& Chen, J. (2002). Asymmetric correlations of equity portfolios. Journal of Financial Economics, 63(3), 443-494. doi:10.1016/S0304-405X(02)00068-5

Bekaert, G., Hordick, R. J., \& Zhang, X. (2009). International stock return comovements. The Journal of Finance, 64(6), 2591-2626. doi:10.1111/j.1540-6261.2009.01512.x

Benjelloun, H. (2010). Evans and archer - Forty years later. Investment Management and Financial Innovations, 7(1), 98-104.

Bouslama, O., \& Ouda, O. B. (2014). International portfolio diversification benefits: The relevance of emerging markets. International Journal of Economics and Finance, 6(3), 200-215. doi:10.5539/ijef.v6n3p200

Cambell, J. Y., Lettau, M., Malkiel, B. G., \& Xu, Y. (2001). Have individual stocks become more volatile? An empirical exploration of idiosyncratic risk. The Journal of Finance, 56(1), 1-43. doi:10.1111/0022-1082.00318

Christoffersen, P., Errunza, V. R., Jacobs, K., \& Langlois, H. (2012). Is the potential for international diversification disappearing? A dynamic copula approach. Review of Financial Studies, 25(12), 3711-3751. doi:10.2139/ssrn.2066076

Danielsson, J. (2011). Financial Risk Forecasting. Chichester, UK: John Wiley \& Sons Ltd.

Dbouk, W., \& Kryzanowski, L. (2009). Diversification benefits for bond portfolios. The European Journal of Finance, 15(5-6), 533-553. doi:10.1080/13518470902890758

De Santis, R. A., \& Sarno, L. (2008). Assessing the benefits of international portfolio diversification in bonds and stocks. Working Paper Series No 883, European Central Bank.

De Miguel, V., Garlappi, L., \& Uppal, R. (2009). Optimal versus naive diversification: How inefficient is the $1 / \mathrm{N}$ portfolio strategy? The Review of Financial Studies, 22(5), 1915-1953. doi:10.1093/rfs/hhm075

Domian, D. L., Louton, D. A., \& Racine, M. D. (2007). Diversification in portfolios of individual stocks: 100 stocks are not enough. Financial Review, 42(4), 557-570. doi:10.1111/ j.1540-6288.2007.00183.x

Elton, E. J., Gruber, M. J., Brown, S. J., \& Goetzmann, W. N. (2011). Modern Portfolio Theory and Investment Analysis. Hoboken, New Jersey: John-Wiley \& Sons Inc. 
Evans, J. L., \& Archer, S. H. (1968). Diversification and the reduction of dispersion: An empirical analysis. The Journal of Finance, 23(5), 761-767. doi:10.1111/j.1540-6261.1968. tb00315.x

Francis, J. C., \& Kim, D. (2013). Modern Portfolio Theory: Foundations, Analysis and New Developments. Hoboken, New Jersey: John Wiley \& Sons, Inc.

Grubel, H. G. (1968). Internationally diversified portfolios: Welfare gains and capital flows. The American Economic Review, 58(5), 1299-1314.

Jaksic, M. (2012). Risk management of portfolio securities. Economichorizons, 14(3), 155-168. doi:10.5937/ekonhor1203151J

Jakšić, M., \& Leković, M. (2015). Upravljanje investicionim rizikom primenom savremene portfolio teorije. Megatrend revija, 12(1), 31-46.

Jiang, C., Ma, Y., \& An, Y. (2013). International diversification benefits: An investigation from the perspective of Chinese investors. China Finance Review International, 3(3), 225-249. doi:10.1108/CFRI-06-2012-0071

Kritzman, M., Page, S., \& Turkington, D. (2010). In defense of optimization: The fallacy of 1/N. Financial Analysts Journal, 66(2), 31-39. doi:10.2469/faj.v66.n2.6

Kunovac, D. (2011). Asymmetric correlations on the Croatian equity market. Financial theory and practice, 35(1), 1-24.

Levy, H., \& Lerman, Z. (1988). The benefits of international diversification in bonds. Financial Analysts Journal, 44(5), 5664. doi:10.2469/faj.v44.n5.56

Li, K., Sarkar, A., \& Wang, Z. (2003). Diversification benefits of emerging markets subject to portfolio constraints. Journal of Empirical Finance, 10(1-2), 57-80. doi:10.1016/S09275398(02)00027-0

Longin, F., \& Solnik, B. (2001). Extreme correlation of international equity markets. The Journal of Finance, 56(2), 649-676. doi:10.1111/0022-1082.00340

Mansourfar, G., Didar, H., \& Jodatnia, S. (2017). International portfolio diversification at industry level within South-East Asian stock markets. Iranian Journal of Management Studies (IJMS), 10(1), 91-112. doi:10.22059/ijms.2017.137736.671892

Markowitz, H. M. (1952). Portfolio selection. The Journal of Finace, 7(1), 77-91. doi:10.1111/j.1540-6261.1952.tb01525.x
Markowitz, H. M. (1999). The early history of portfolio theory: 1600-1690. Financial Analysts Journal, 55(4), 5-16. doi:10.2469/ faj.v55.n4.2281

McEnally, W. R., \& Boardman, M. C. (1979). Aspects of corporate bond portfolio diversification. The Journal of Financial Research, 2(1), 27-36. doi:10.1111/j.1475-6803.1979. tb00014.x

Omisore, I., Yusuf, M., \& Christopher, N. (2012). The modern portfolio theory as an investment decision tool. Journal of Accounting and Taxation, 4(2), 19-28. doi:10.5897/JAT11.036

Ramchand, L., \& Susmel, R. (1997). Volatility and cross correlation across major stock markets. Journal of Empirical Finance, 5(4), 397-416. doi:10.1016/S0927-5398(98)00003-6

Rubinstein, M. (2002). Markowitz's portfolio selection: A fifty-year retrospective. Journal of Finance, 57(3), 1041-1045. doi:10.1111/1540-6261.00453

Sharpe, W. F., Alexander, G. J., \& Bailey, J. V. (1995). Investments. Englewood Cliffs, New Jersey: Prentice Hall Inc.

Solnik, B. H. (1974). Why not diversify internationally rather than domestically? Financial Analysts Journal, 30(4), 48-54. doi:10.2469/faj.v51.n1.1864

Statman, M. (1987). How many stocks make a diversified portfolio? Journal of Financial and Quantitative Analysis, 22(3), 353-363. doi:10.2307/2330969

Statman, M. (2002). How much diversification is enough? Working paper, Santa Clara University. doi:10.2139/ ssrn.365241

Tang, G. Y. N. (2004). How efficient is naive portfolio diversification? An educational note. Omega, 32(2), 155-160. doi:10.1016/j.omega.2003.10.002

van Horne, J. C., \& Wachowicz, J. M. (2007). Osnovi finansijskog menadžmenta. Beograd, Republika Srbija: Data status.

Vincent, S. (2011). Is portfolio theory harming your portfolio? Journal of Applied Research in Accounting and Finance, 6(1), 2-13. doi.org/10.2139/ssrn.1840734

Williams, J. B. (1938). The Theory of Investment Value. Cambridge, USA: Harvard University Press.

You, L., \& Daigler, R. T. (2010). Is international diversification really beneficial? Journal of Banking \& Finance, 34(1), 163-173. 
Primljeno 17. aprila 2018, nakon revizije, prihvaćeno za publikovanje 22. avgusta 2018. Elektronska verzija objavljena 27. avgusta 2018.

Miljan Leković je docent na Fakultetu za hotelijerstvo i turizam u Vrnjačkoj Banji Univerziteta u Kragujevcu, na nastavnim predmetima Osnovi ekonomije i Nacionalna ekonomija. Doktorirao je na Ekonomskom fakultetu Univerziteta u Kragujevcu. Oblast njegovog naučnog interesovanja je finansijska ekonomija.

\title{
INVESTMENT DIVERSIFICATION AS A STRATEGY FOR REDUCING INVESTMENT RISK
}

\author{
Miljan Lekovic \\ Faculty of Hotel Management and Tourism in Vrnjacka Banja, \\ University of Kragujevac, The Republic of Serbia
}

Investment diversification is a widely accepted investment strategy, aimed at reducing investment uncertainty, while simultaneously keeping the expected return on investment unaltered. The development of investment diversification coincided with the development of portfolio theory. At the time when traditional portfolio theory was recognized as the leading portfolio management practice, the simple diversification of investments was the most commonly used strategy; however, due to its inability to recognize the importance of the correlation between returns on different investments, simple diversification was later rejected in modern portfolio theory and replaced with efficient diversification. The research study is aimed at conducting a comparative analysis between the simple and efficient diversifications of investments, together with the inevitable analysis of the optimal number of securities in a portfolio and the testing of the validity of the international diversification of investments. By applying a qualitative research methodology, it is concluded that the benefits of the international diversification of investments are still substantial, and as such outweigh specific limitations, and that the number of securities in a portfolio should be increased as long as its marginal benefits, in the form of reduced investment risk, exceed its marginal costs - in terms of increased portfolio management costs, which also represents the main result of the research.

Keywords: simple diversification, efficient diversification, national diversification, international diversification 